\title{
Kurumsal Kredi Skorlamasında Klasik Yöntemlerle Yapay Sinir Ağı Karşılaştırması
}

\section{A Comparison of the Artificial Neural Network with Classical Methods in Corporate Credit Scoring}

\section{Şahap KAVCIOĞLU1 ${ }^{1}$}

\section{öz}

Bankaların, müşterilerinin kredi değerliliğini doğru bir şekilde analiz etmemeleri yıkıcı sonuçlar doğurmaktadır. Bu nedenle, bankacııık sektöründe kredi skorlamasının önemi son yıllarda büyük bir araştırma alanı haline gelmiştir. Kredi değerliliğinin skorlanması için lojistik regresyon, doğrusal regresyon, diskriminant analizi ve yapay sinir ağları gibi yöntemler mevcuttur. Bu araştırmanın konusu makine öğrenmesi ve lojistik regresyon modellerinin kredi skorlaması modelindeki performanslarınnı kıyaslama yoluyla değerlendirmektir. Bu çalışma ile klasik yöntemlerle yapay sinir ağlarını karşılaştırarak, bankaların kredi riskine en az düzeyde maruz kalabilecekleri bir skorkart modeli geliştirilmesi amaçlanmıştır. Literatürde kredi skorlaması modellerinin kıyaslanmasına ilişkin çalışmalar mevcut olmakla birlikte, çalışmalar perakende portföyler üzerinden ve en fazla 4 yılı kapsayan bir örneklem üzerinden yapılmıştır. Araştırma literatürdeki çalışmalardan farklı olarak kurumsal firmalar üzerinden ve literatürdeki çalışmalara göre daha geniş bir örneklem üzerinden ele alınmıştır. Çalışma sonucunda geliştirme örnekleminde daha yüksek başarı sergileyen yapay sinir ağlarının, örneklem dışı veri seti üzerinde lojistik regresyondan daha düşük bir performans sergilediği görülmüştür. Böylece yapay sinir ağları yüksek performans gösterse de, lojistik regresyonun daha tutarlı sonuçlar verdiği bulgusuna ulaşıımakla birlikte yapay sinir ağlarının iterasyon süreçlerinde optimizasyon yapılması ile daha tutarlı sonuçlar üretebileceği düşünülmektedir.

Anahtar kelimeler: Yapay sinir ağları, lojistik regresyon, kredi skorlama modelleri

JEL Sınıflaması: C45, C51, G21

\section{ABSTRACT}

The failure of banks to correctly analyze the credit worthiness
${ }^{1}$ Assoc. Prof. Dr., Marmara University, School of Banking and Insurance, Department of Banking, Istanbul, Turkey

ORCID: Ş.H. 0000-0003-4622-7668

Corresponding author/Sorumlu yazar: Şahap KAVCIOČLU,

Marmara University, School of Banking and Insurance, Department of Banking, Istanbul, Turkey

E-mail/E-posta: sahap.kavcioglu@marmara.edu.tr

Submitted/Başvuru: 04.10.2019

Revision Requested/Revizyon Talebi:

14.11.2019

Last Revision Received/Son Revizyon:

19.11.2019

Accepted/Kabul: 02.12.2019

Citation/Atıf: Kavcioglu, S. (2019). Kurumsal kredi skorlamasında klasik yöntemlerle yapay sinir ağı karşılaştırması. Istanbul iktisat Dergisi - Istanbul Journal of Economics, 69(2), 207-245. https://doi.org/10.26650/ISTJECON2019-0021 
of their customers has devastating consequences. Therefore, the importance of credit scoring in the banking sector has become a major field of research in recent years. There are some methods such as logistic regression, linear regression, discriminant analysis and artificial neural networks for credit scoring. The subject of this research is to evaluate the performance of machine learning and logistic regression models on credit scoring by comparison. In this study, it is aimed to develop a scorecard model in which banks can be exposed to a minimum level of credit risk by comparing the logistic regression and artificial neural network methods which are two of these methods. Although there are studies on the comparison of credit scoring models in the literature, the studies have been conducted through retail portfolios and a sample that covers a maximum of 4 years. Unlike the studies in the literature, this research was conducted through corporate firms and a larger sample than the studies in the literature. The result of the study indicated that artificial neural networks which have higher success than logistic regression on the development sample, saw lower success on the out of sample data. Thus, while artificial neural networks show higher performance, it is concluded that logistic regression provides more consistent results, and it is thought that artificial neural networks can produce more consistent results by optimization of the iteration processes.

Keywords: Artificial neural networks, logistic regression, credit scoring models

JEL Classification: C45, C51, G21

\section{EXTENDED ABSTRACT}

In the banking sector, credit risk is one of the most important risk types that needs to be managed by banks. Banks have applied many different methods in order to measure credit risk. In this context, various statistical methods have been used in recent years in order to quickly and objectively measure the credit risk of customers. Regulators have set various standards and regulations for the use and spread of these statistical methods.

In the first part of the study, an overview of the traditional model methodologies is given and in the next part, general information about the artificial neural networks which is one of the machine learning methodologies is given. Linear, logistic regression and discriminant analysis methods used in credit scoring are mentioned on a general level. Artificial neural networks are discussed in detail, the general structure of the model is explained and artificial neural network classifications in the literature are mentioned.

The aim of this study is to develop a scorecard model in which banks can be exposed to a minimum level of credit risk. To this end, scorecard models were 
developed using logistic regression and artificial neural network methods, which are credit scoring methods, and the obtained model results were compared. In this study, 8 years of data which includes the financial information and repayment habits of companies operating in the manufacturing, service and trade sectors in the corporate segment between 2010 and 2017 was used. The models in the study were developed through SPSS Modeler program.

The modular structure was preferred for logistic regression and financial and behavioral modules were created using the stepwise logistic regression method with $5 \%$ margin of error. The integration of modules was made by the enter method of logistic regression, thus it was possible that both modules could take part in module integration.

Unlike the logistic regression method, the modular structure was not used while developping the artificial neural network method. The variables in two different modules used in logistic regression were combined and the artificial neural network model was established over this single variable list. In the study, $80 \%$ of the data was allocated as learning and $20 \%$ of the data was allocated as test in the whole data set. After various analyses, 18 financial and 11 behavioral input variables were used in the model. In addition, the model consisted of 3 layers: 1 input layer, 1 hidden layer and 1 output layer. Considering the model's technical aspects, the Sigmoid function was used as an activation function. The learning coefficient and the momentum coefficient were determined automatically by SPSS Modeler.

In the last part, ROC curves and Gini coefficients were compared to evaluate the model developed by the logistic regression and artificial neural network methods. The evaluation of the models was carried out both by the development sample and the out of sample data. In the development sample, the artificial neural network model which performed with a 0.76 Gini value showed a higher success than the logistic regression model which performed with a 0.56 Gini value. However, it was observed that artificial neural networks performed with a 0.60 Gini value which is less than the logistic regression 0.69 Gini value on the out of 
sample data set that was not included in the modeling process. According to this result, logistic regression was more consistent. However, it is thought that artificial neural networks can produce more consistent processes with the optimization of iteration processes.

As a result of this study, it is foreseen that traditional methods such as logistic regression will continue to be preferred in credit scoring and adopted by regulation as they are more comprehensible and produce consistent results. It is thought that artificial neural networks, which is one of the systems based on machine learning, will be developed and used in both credit scoring and customer service related areas. 


\section{Giriş}

Dünya'da son yıllarda bankacılık sektörü hızlı bir gelişim göstermiştir. Bankaların hem ulaştığı müşteri sayısında hem de bankacılık sistemi üzerinden kullandırılan kredi tutarlarında çok ciddi artışlar yaşanmıştır. Türkiye 'de güncel veriler ele alındığında 2019 yılının Haziran ayı itibariyle Bankalar tarafından kullandırılan nakdi kredilerin miktarı 2.576 milyar TL tutarındadır (Risk Merkezi, 2019). Bu durum bankaları, ekonomik sağlamlığın sağlanması ve büyümenin sürdürülebilirliği açısından önemli bir konuma getirmektedir. Günümüzde sağlam bir ekonomiye sahip olabilmenin koşulu sağlam bir bankacılık sektörüne sahip olmaktır (Dinçer, Yüksel ve Hacıoğlu, 2016).

Bankacılık sektörünün ülke ekonomileri üzerinde etkin bir role sahip olması, hem uluslararası hem de ulusal otoriteleri, bankalara ilişkin çeşitli düzenlemeler yapmaya sevk etmiştir (Uruş, 2019). Bankaların en temel fonksiyonu çeşitli yöntemlerle ile topladıkları fonları, fon talep edenlere aktarmalarıdır. Kamuyu Aydınlatma Platformunda belirtilen bilanço verileri göz önünde bulundurulduğunda, bankaların kullandırdığı kredi tutarının toplam bilanço üzerinde ağırlığı oldukça yüksek olduğu görülmektedir (KAP, 2019). Kredilerin banka bilançosunda önemli yer tutması, kredi riskinin doğru şekilde yönetilmesini elzem bir konu haline getirmektedir.

Geçmiş dönemlere bakıldığında farklı ülkelerde yaşanan birçok krizin, kredi tahsis süreçlerinin yanlış yönetilmesinden, bir başka ifade ile kullandırılan kredilerin geri ödenmemesinden kaynaklandığı görülmektedir (Chih-Fong ve Jhen-Wei, 2008). Bu doğrultuda bankaların sahip oldukları fonları doğru bir şekilde yönetmesi hem sektörün hem de ekonominin sağlıklı büyümesi açısından önemli bir husus olarak ön plana çıkmaktadır.

Kredi yönetiminin doğru şekilde yapılmamasının yıkıcı sonuçları, bankaları kredi talep eden müşterilerini detaylı değerlendirme yöntemleri kullanarak incelemeye sevk etmiştir (Soydemir, 2019). Bu bağlamda bankalar ilk etapta kredi talep eden müşterilerini kredi tahsis bölümlerinde çalışan personellerinin 
deneyimleri üzerinden oluşturdukları subjektif kriterler ile değerlendirmeye başlamışlardır. İlgili dönemlerde bankalar, görevlendirdiği personel aracılığı ile personelin edindiği bilgileri ve gözlemlerini dikkate alarak uzman görüşüne dayalı ve subjektif bir şekilde kredi talep edenleri değerlendirmekteydi (Marques, Garcia ve Sanchez, 2013).

Veri saklama ve işleme sistemlerin zaman içerisinde gelişmesi bankaların çeşitli istatistiki yöntemler uygulayarak müşterilerini değerlendirmesine olanak sağlamıştır. Böylelikle banka çalışanları tarafından yapılan subjektif değerlendirmelerin önüne geçilmiştir (Abdou ve Pointon, 2011). Ayrıca Basel II süreciyle yasal otoritelerin sermaye yeterliliği hesaplamalarında kredi riskine esas tutarın içsel derecelendirmeye dayalı yaklaşımlar ile hesaplanmasına imkân tanıması sonucunda bankaların tarihsel verilerine dayanan kredi süreçlerinde yeknesak karar verme olanağı sağlayan modeller geliştirilmeye başlanmışıı (Türkiye Bankalar Birliği, 2006).

Sektör uygulamalarında kredi skor model algoritmalarının dayandığı yapının şeffaf olmasının model yönetimi ve açıklanabilirliği hususunda yarattığı pratikliğin yanı sıra yasal otoritelerce sermaye hesaplamasına konu edilmesinin kabul görmesi nedeniyle genel olarak lojistik regresyon, doğrusal regresyon gibi istatiksel yöntemler ile oluşturulan modeller kullanılmaktadır. Kredi skorlamasında bu yöntemler, klasik yöntemler olarak sınıflandırılmaktadır (Zekic-Susac, Bensic ve Sarlija, 2005). Ayrıca makine öğrenmesi algoritmaları da modelleme çalışmalarına konu edilmeye başlanmıştır.

Çalışmanın konusu makine öğrenmesi ve lojistik regresyon modellerinin kredi skorlaması modelindeki sonuçlarını ortaya koyup yöntemleri birbiriyle kıyaslayarak değerlendirmektedir. Çalışmanın amacı ise kredi skorlama modellerinin daha başarılı sonuçlar vermesini sağlamaktır. Literatürde yapay sinir ağları modelleri üzerine çalışmalar ve yapay sinir ağları modellerinin klasik modellerle kıyaslanması üzerinden değerlendirmeler yapılmış olmakla birlikte, konu kurumsal firmalar üzerinden ele alınmamıştır. Ayrıca çalışma örneklem dönemi (2010 ve 2017 yıllarını kapsayan 8 yıllık dönem) açısından da literatürden farklılaşmaktadır. 
Çalışma sonucunda yapay sinir ağları modelinin model geliştirme verileri daha iyi sonuçlar üretse de, lojistik regresyon çıktılarının örneklem dışı verilerde daha tutarlı olduğu bulgusuna ulaşılmıştır.

\section{Kavramsal Çerçeve}

Kavramsal olarak çerçevenin oluşturulabilmesi için öncelikle kredi skorlama kavramı ele alınmış, ardından da kredi skorlama yöntemlerine değinilip yapay sinir ağları yöntemi detaylandırılmıştır.

\subsection{Kredi Skorlaması Kavram Tanımı}

Kredi, satın alma gücünün gelecek zamanda ödeme taahhüdü alarak devredilmesi olarak tanımlanmaktadır (Irwin, 1965). Finansal sistemlerin gelişmesiyle beraber kredi veren kurumların ekonomi içerisindeki ağıllığı ve kredi hacmi artma eğilimi göstermektedir (Türkiye Cumhuriyeti Merkez Bankası, 2019).

Kredi talep eden müşterilerin sayısındaki ciddi artış ile birlikte kredi kullandıran kurumların sahip oldukları kaynakları doğru şekilde yönetmeleri elzem bir konu haline gelmiştir. Bu doğrultuda kıt kaynakların etkin yönetimini sağlamak ve kredi değerlendirme sürecini otomatikleştirmek için kredi skorlama yöntemlerine ihtiyaç duyulmuştur. Kredi skorlaması, kredi başvurusunda bulunan gerçek veya tüzel kişilerin gözlemlenebilen geçmiş verilerinden faydalanarak oluşturulan, gelecekteki temerrüte düşme durumunu analiz etmeye yönelik bir değerlendirme yöntemidir. Kredi skorlaması için önceden ekspertiz modelleri olarak da bilinen banka çalışanı yetkililerin öznel olarak değerlendirmelerine dayalı yöntemler kullanılmaktaydı. Kredi hacminin genişlemesiyle beraber riskin daha iyi yönetilebilmesi adına istatistiki yöntemler de müşteri kredibilitesini değerlendirmeye dahil edilmiştir (Öker, 2007).

\subsection{Kredi Skorlama Yöntemleri}

Kredi skorlamasında klasik yöntemler sayılan doğrusal, lojistik regresyon yöntemleri ile diskriminant analizi ele alınmıştır. Bu yöntemler aşağıda 
detaylandırılarak açıklanmışır. Klasik yöntemlerin yanında makine öğrenmesine dayalı yapay sinir ağları yöntemine de detaylı olarak yer verilmiştir.

\subsubsection{Doğrusal Regresyon}

Doğrusal regresyon, temel ve yaygın olarak kullanılan, geçmiş verilerden yola çıkarak gelecek tahminine dayalı bir analiz türüdür. Bu regresyon tahminleri, bir bağımlı değişken ile bir veya daha fazla bağımsı değişken arasındaki ilişkiyi açıklamak ve özellikle hangi değişkenler için açıklayıcılık durumunun daha fazla olduğunu bulabilmek için kullanılır (Taylan ve Aydın, 2018).

Çok değişkenli doğrusal regresyon denkleminin gösterimi aşağıdaki formül ile tanımlanır. Burada $Y$ tahmini bağımlı değişkeni, $\beta_{0}$ sabit katsayıyı, $\beta_{n}$ regresyon katsayısını ve $X_{n}$ bağımsız değişkenleri temsil etmektedir.

$$
\mathrm{Y}=\beta_{0}+\beta_{1} \cdot X_{1}+\beta_{2} \cdot X_{2}+\ldots \beta_{n} \cdot X_{n}
$$

Çoklu doğrusal regresyon analizlerinde diğer geleneksel regresyon analizlerinde olduğu gibi çeşitli varsayımların uygunluğu aranmaktadır. Söz konusu varsayımlar; hataların normal dağılıma uygunluk göstermesi, hataların eş varyansa sahip olması, hata terimleri arasında otokorelasyon gözlemlenmemesi, değişkenler arası çoklu doğrusal bağlantı gözlemlenmemesi hataların ortalamalarının sıfır olması ya da sıfıra yakınsaması olarak sıralanır.

\subsubsection{Lojistik Regresyon}

Kredi skorlamasında yaygın olarak kullanılan modelleme tekniklerinden bir tanesi lojistik regresyondur (Han, Han ve Zhao, 2013). Lojistik regresyon analizinde bağımlı değişken ikili değerler almaktadır ancak bağımsız değişkenler kesikli, sürekli ya da sıralı olabilmektedir (Kılıç, 2015). Lojistik regresyona ilişkin denklem gösterimine aşağıda yer verilmiş̧ir (Donel, 2012):

$$
\operatorname{Ln}[\mathrm{p} /(1-\mathrm{p})]=\alpha+\beta_{1} \cdot X_{1}+\beta_{2} \cdot X_{2}+\ldots \beta_{\mathrm{n}} \cdot X_{\mathrm{n}}
$$


Yukarıda yer alan modelde $p$ ifadesi olasılık değerini, a sabit katsayıyı, $\beta$ değerleri ilgili değişkenlerin katsayılarını ve $x$ değerleri ise modeldeki bağımsız değişkenleri ifade etmektedir.

Lojistik regresyon son yıllarda ikili sonuç üreten bir yapıya sahip olması, sonuç olasılıklarının 0 ile 1 arasında kalması ve performansının yüksek olması dolayı kredi skorlaması alanında en çok kullanılan modellerden birisi olmuştur. (Donel, 2012). Ayrıca lojistik regresyonun normal dağılım, sabit varyans gibi doğrusal regresyonun varsayımlarına gereksinim duymaması ve sonuçlarının kolay yorumlanabilir olması birçok araştırmacı tarafından söz konusu modelin tercih edilmesine vesile olmuştur (Koç, 2018).

\subsubsection{Diskriminant Analizi}

Diskriminant analizi 1936 yılının başlarında Fisher tarafından lojistik regresyonun bir ikamesi olarak geliştirilmiş bir metottur (Hooman ve ark., 2016). Diskriminant analizi, kategorik biçimde belirlenmiş bağımsız ve bağımlı değişkenlerin arasında işlevsel bir ilişki kurup, gruplar arasında ayrım yapabilmeyi sağlayan bir yöntemdir (Malhotra ve Malhotra, 2002). Diğer bir ifadeyle, değişkenlere bağlı olarak, gruplar arasında ayırt edici bir farkın olup olmadığını incelemektedir (Kurtaran Çelik, 2010).

Doğrusal diskriminant analizi, normal dağılım, çoklu doğrusal bağlantı olmaması, varyans ve kovaryans matrislerinin homojenliği gibi varsayımlara ihtiyaç duymaktadır (Yakut ve Elmas, 2013). Diskriminant analizinin diğer modellere nazaran daha kolay yorumlanabilmesi ve büyük örnekleme sahip kitlelerde etkin sonuçlar vermesi sebepleriyle finansal başarısızlık çalışmalarında yaygın olarak kullanılmaktadır (Kurtaran Çelik, 2010). Kredi skorlaması alanında ise diskriminant analizinin çeşitli varsayımlara ihtiyaç duyması ve uç değerlere olan hassasiyeti sebebiyle daha az tercih edilmektedir (Niklis, Doumpos ve Zopounidis, 2012).

\subsubsection{Yapay Sinir Ağları}

Yapay sinir ağları, insan beyni yapılarının fizyolojik yapısını ve işleyişini yapay olarak simüle etme arzusundan doğmaktadır. Girdi-çıktı arasındaki ilişki 
örneklerinin modellemesini insan beyninin özelliklerinden olan öğrenme yoluyla yeni bilgiler türetebilme, keşfedebilme gibi çalışma prensiplerini ve sinir sistemi davranışlarını taklit ederek ortaya koyan adaptif bir veri işleme yaklaşımıdır. Bir diğer ifade ile yapay sinir ağları, çok değişkenli ve değişkenlerin kendi aralarında düzenli olmadığı fakat karşılıklı etkileşimin bulunduğu veya tek bir çözüm kümesinin bulunmadığı durumlarda kullanılan bir yapay zeka teknolojisi olarak ifade edilebilir (Pacelli ve Azzollini, 2011).

İnsan beyninin işleyiş sistemine benzeyen yapay sinir ağları, tıpkı insan beyninde olduğu gibi kendisine gelen bilgileri bir nörondan diğerine aktarır (Ersoy ve Karal, 2012). Söz konusu aktarım nöronların aralarında sahip olduğu bağlantılar üzerinden gerçekleşmektedir. Her bir bağlantı farklı ağılıklara sahip olup, sinyalleri ile çarpılmaktadır (Ataseven, 2013). Her nöron bir aktivasyon fonksiyonuna sahip olup bu aktivasyon formülü vasıtasıly çıktı sinyalini oluşturmaktadır. Yapay sinir ağları kendisine öğretilen bir veri setine karşılık gelebilecek bir çıktı seti belirler. Bunu yaparken öğrenme aşamasında kullanılan veri seti aracılığıyla genelleme yapma yeteneğini kazanır ve böylece benzer olaylara karşılık gelen çıktı setini ortaya koyar.

Yapay sinir ağlarının kısıtlı bilgi ile çalışabiliyor olması, zor problemleri çözme yetenekleri ve karmaşık yapıları açıklamadaki gücü dikkate alındığında günümüzde örüntü tanıma, sınıflandırma, optimizasyon, sinyal filtreleme ve zaman serisi analizleri gibi birçok farklı alanda kullanılmaktadır. Son yıllarda bankacılık alanında yapay zeka tekniklerinin bankacılar açısından kredi vermede, piyasanın gelişimine katkıda bulunmada ve dolandırıcılık tespiti gibi alanlarda önemli bir rol oynadığı hakkında birçok çalışma yayınlanmıştır (Desai, Crook ve Jr. Overstreet, 1996). Yapay zeka tekniklerinin kullanıldığı sınıflandırma ve ekonomik durumların ayrıştırılmasına yönelik çalışmalar arasında, özellikle kredi riskinin yönetiminde yapılmış olan çalışmalar dikkat çekmiştir (Pacelli ve Azzollini, 2011).

Yapay sinir ağlarında bulunan yapay sinir hücrelerine işlem elemanı veya süreç elemanı denilmektedir. Süreç elemanlarının birbirine bağlandıkları ve her bağlantının bir değerinin olduğu kabul edilmektedir. Bir yapay sinir ağı birbiriyle 
bağlantılı çok sayıda yapay sinir hücresinden meydana gelmektedir. Yapay sinir ağlarının içinde bulunan tüm sinir hücreleri bir veya birden fazla girdi alıp tek bir çıktı verirler. Bu çıktı yapay sinir ağının dışına verilen bir çıktı olabileceği gibi başka bir yapay sinir hücresine girdi niteliği de taşıyabilir.

Yapay sinir ağları, ileri beslemeli ve geri beslemeli ağlar şeklinde ikiye ayrılmaktadır. Illeri beslemeli ağlar genel olarak çok katmanlı bir yapıya sahiptir. İleri beslemeli ağlarda, giriş katmanı dış ortamdan aldığı bilgileri hiçbir değişikliğe uğratmadan orta (gizli) katmandaki hücrelere iletir. Bilgi, orta katmanda işlenerek çıkış katmanına iletilir. Çıkış katmanına gelen bilgi çıkış katmanında belirtilen fonksiyon ile değerlendirmeye alınarak sonuç çıktısı elde edilir. Oluşan çıktı değerleri ile istenilen değerler karşılaştırılarak hata oranları oluşturulur. Oluşturulan hata oranları ile ağırlıklar tekrardan güncellenir. Gerçekleşen tüm bu işlem adımlarında bilgi sadece bir sonraki katmana gidecek şekilde tek yönlü olarak ilerlemektedir. İleri beslemeli ağlara örnek olarak, Çok Katmanlı Algılayıcı (Multi Layer Perceptron -MLP) ve Doğrusal Vektör Parçalama (Linear Vector Quantization - LVQ) ağları verilebilir (Alavala, 2007).

$$
\gamma=\sum_{j=1}^{M} w_{\mathrm{j}} \Phi_{\mathrm{j}}\left(\mathrm{u}_{\mathrm{j}} \mathrm{XX}+\mathrm{u}_{\mathrm{j} 0}\right)+\mathrm{w}_{0} .
$$

Yukarıda belirtilen denklem çok katmanlı yapay sinir ağı için kullanılmakta olup iki katmanlı ileri beslemeli yapay sinir ağına oldukça benzemektedir. $\mathrm{j}=1$, ..., M ifadesi M'e kadar olan katman sayısını , x giriş vektörünü , $\Phi_{j}$ aktivasyon fonksiyonunu $\gamma$ ise çıktıyı, wj bağlantı ağılıklarını temsil etmektedir (Bishop, 1995). Geri Beslemeli yapay sinir ağlarında ağın süreç elemanlarının çıktıları yeniden ağa geri gönderilerek girdi olarak kullanılmaktadır. Bu çeşit sinir ağlarının dinamik hafızaları vardır ve bir andaki çıkış, hem o andaki hem de önceki girişleri yansıtır. Bu geri dönüşümlerin olması özellikle zaman gecikmelerinin göz önüne alınması hususunda önem arz etmektedir. Bundan dolayı, özellikle tahmin uygulamalarında kullanılırlar. Bu ağlar çeşitli tipteki problemlerin tahmininde oldukça başarı sağlamışlardır. Bu ağlara örnek olarak; Hopfield, Düzenleyici Harita (Self Organizing Map - SOM), Elman ve Jordan ağları verilebilir (Alavala, 2007). 


\section{Şekil 1: Yapay Sinir Ağlarının Yapısı}

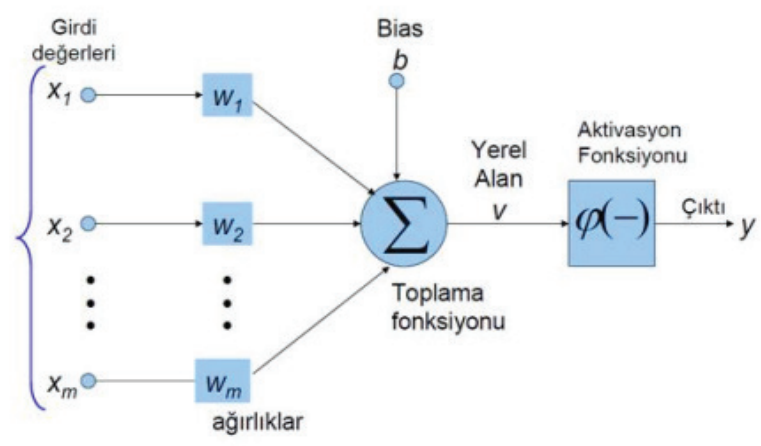

Kaynak: Keskenler \& Keskenler, 2017.

Yapay sinir ağlarının yapısı incelendiğinde içerisinde bulunan süreç elemanları paralel bir şekilde birbirine bağlanarak her bir katmanı oluştururlar. Katmanlar ise bir araya gelerek yapay sinir ağı sistemini oluştururlar. Söz konusu sistem genel olarak girdi katmanı, ara katman ve çıktı katmanı olmak üzere 3 ana katmandan oluşmaktadır (Öztemel, 2012).

Yapay sinir hücrelerini dış dünyadan besleyen işlenmemiş bilgilere girdi denir. Girdi katmanı dışarıdan girdileri alan nöronları (sinirleri) içerir ve girdi değerlerini bir sonraki katmana iletir. Yapay sinir ağı içinde girdilerin hücreler arasında iletimini sağlayan tüm bağlantıların farklı ağırlık değerleri bulunur. Veriler (bilgiler) bağlantılar üzerindeki ağılıklar üzerinden hücreye girer ve ağırlıklar yapay sinirde kullanılacak değerlerin göreceli kuvvetini gösterir. Hücreye gelen girdiler kendi ağırlıkları ile çarpılmakta sonrasında bir fonksiyon kullanılarak işlenmektedir. Bu aşamada yaygın olarak toplama fonksiyonu kullanılmaktadır. Toplama fonksiyonundan gelen girdiyi işleyerek yapay sinir hücresinin çıkısını belirleyen fonksiyon aktivasyon (transfer) fonksiyonudur (Çevik ve Dandıl, 2012). Bu fonksiyon veriye veya ağın neyi öğrenmesi isteğine bağlıdır. Diğer bir ifade ile aktivasyon fonksiyonu toplama fonksiyonundan gelen girdiyi dönüştürerek istenilen değerler arasında sınırlandıır. Çoğu durumda aktivasyon işleminden geçen ağırlıklandırılmış girdi değerlerinin çıktısı -1 ile 1 arasında veya 0 ile 1 arasında değerler almaktadır. 
Yapay sinir hücre modellerinde yaygın olarak kullanılan aktivasyon fonksiyonlarının ilki doğrusal problemlerin çözümünde kullanılmakta olan ve gelen net girdileri doğrudan hücre çıkışı olarak veren doğrusal aktivasyon fonksiyonudur. İkincisi ise gelen net girdi değerinin belirlenen bir eşik değerinin altında ya da üstünde olmasına göre hücre çıktısının 1 veya 0 değerlerini aldığı fonksiyon olan adım fonksiyonudur. Üçüncüsü sürekli ve doğrusal olmayan bir fonksiyon olması nedeniyle uygulamada en çok kullanılan aktivasyon fonksiyonu olan sigmoid aktivasyon fonksiyonudur. Sigmoid aktivasyon fonksiyonu türevi alınabilir, net girdinin her değeri için 0 ile 1 arasında bir değer üretmektedir. Son olarak hiperbolik tanjant fonksiyonu ise gelen net girdinin tanjant fonksiyonundan geçirilmesi ile hesaplanmaktadır ve sigmoid aktivasyon fonksiyonunun farklı bir çeşididir. Sigmoid aktivasyon fonksiyonunda çıktı 0 ile 1 arasında bir değer alırken, hiperbolik tanjant fonksiyonunda çıktı -1 ile 1 arasındadır (Ballı, 2014).

Transfer fonksiyonundan elde edilen değer yapay sinir hücresinin çıkısını oluşturur. Çıktı katmanı ise yapay sinir ağının en uç katmanıdır. Gizli katmandan aldığı veriyi ağın kullandığı fonksiyonla işleyerek ara katmandan gelen çıktıları dış ortama ileten nöronları içeren katmandır. Bu çıktı değeri başka bir yapay sinir hücresine girdi ya da dış ortama gönderilebilir (Çevik ve Dandıl, 2012).

Yapay sinir ağları öğrenme yöntemlerine göre danışmanlı öğrenme, danışmansız öğrenme ve takviyeli öğrenme olmak üzere 3 şekilde sınıflandırılmaktadır. Danışmanlı (gözetimli) öğrenme sisteminde her bir eğitim aşamasında; nihai sonuç çıktısı ile gerçek çıktı arasındaki fark minimize edilmeye çalışılarak bağlantılar arasındaki fark yenilenerek hata değeri minimize edilmeye çalışılır. Danışmalı öğrenme yöntemi yapay sinir ağlarında en çok kullanılan yöntemlerden bir tanesi olup, özellikle ileri beslemeli ağlarda daha sık uygulanmaktadır. Danışmansız öğrenme yönteminde, sisteme sadece giriş verileri iletilmekte olup, ağa sonuç çıktısına ilişkin bir veri sunulmaz. Sistem giriş verilerinden hareketle kendi kendine öğrenme gerçekleştirerek çıkı sonucunu oluşturmaktadır. Destekleyici öğrenme yönteminde, danışmansız öğrenme yönteminde olduğu gibi ağ sadece giriş verileri üzerinden içsel bir öğrenme yaparak sonuç çıktısı üretmektedir. Sonraki aşamada 
üretilen sonuç çıktısı ile gerçek değerler arasındaki farka göre bir değer üretmektedir. Üretilen değerler üzerinden sistem tekrardan çalıştırılarak ağ bağlantıları kalibre edilmektedir. Söz konusu işlevi hata terimlerini minimize edene kadar devam etmektedir (Bayır, 2006).

\section{Literatür}

Literatürde yapay sinir ağları üzerine çalışmalar yapılmış, kredi skorlaması modellerinde de yapay sinir ağlarının performansı değerlendirilmiştir. Bununla birlikte kredi skorlamasında yapay sinir ağları modelini, lojistik regresyonla müşterilerin temerrüde düşüp düşmeme ihtimalini ayırt edebilme açısından değerlendiren çalışmalar da mevcuttur.

Desai ve ark. (1996), kredi skorlamasında bireysel müşterilerin 1988-1991 yılı verileri üzerinden lojistik regresyon, diskriminant analizi ve yapay sinir ağları yöntemlerini kıyaslamışlardır. Kötü müşterileri (temerrüde düşmüş müşteriler) tahmin etmede yapay sinir ağlarının daha başarılı olduğu, iyi müşterileri (temerrüde düşmemiş müşteriler) tahminleme de ise lojistik regresyonu yakınsayacak performans sergilediği bulgularına ulaşılmışır.

Zekic-Susac, Sarlija ve Bensic (2005), çalışmalarında lojistik regresyon, yapay sinir ağı ve CART (Classification and Regression Tree) karar ağacı üzerinden kredi skorlama yöntemleri karşılaştııılmıştır. Hırvatistan'daki bir bankadan alınan veriler küçük işletmeleri içermektedir. Yapılan analiz sonucunda yapay sinir ağları modeli, diğer modellere göre daha iyi performans sonuçları göstermiştir.

Abdou, Pointon ve El-Masry (2008) çalışmalarında Mısır'daki bir bankanın bireysel müşterilerine ait veriler üzerinden lojistik regresyon, probit regresyon, diskriminant analizi ve yapay sinir ağlarının iki farklı türü olan olasılıksal sinir ağları ve çok katmanlı ileri beslemeli ağ üzerinden kıyaslama yapmışlardır. Değerlendirme için grup varyansları ve Kruskal-Wallis testleri kullanılmıştır. Sonuç bulguları görecelilik gösterirken, en az yanlıss sınıflandırma yapan modelin çok katmanlı ileri beslemeli ağ olduğu sonucuna ulaşılmıştır. 
Budak ve Erpolat (2012), kredi skorlamasını bireysel nitelikli (retail) müşterilerden oluşan örneklem üzerinde lojistik regresyon ve yapay sinir ağları modelini kıyaslayarak değerlendirmişlerdir. 2011 yılı verileri üzerinden kurulan modeller Tip 1 ve Tip 2 hatası yöntemiyle karşılaştııılmış ve kredi skorlamasında yapay sinir ağları modelinin daha başarılı sonuçlar verdiği bulgusuna ulaşılmıştır.

Karimi (2014), çalışmasında 2010-2013 yıllarını kapsayan ve İran ticari bankasından elde ettiği firma bilgilerini içeren örneklem üzerinden lojistik regresyon ve yapay sinir ağları modelleri kurarak kredi skorlama yöntemlerini kıyaslamışır. Tip 1 ve Tip 2 hatası yöntemiyle performas değerlendirmesi yapmış ve sonuç olarak kötü müşterileri tahminlemede yapay sinir ağları daha başarılı performans sergilediği, iyi müşterileri tahminlemede lojistik regresyon modeli daha iyi tahminlediği bulgularına ulaşılmıştır.

Zhu ve ark. (2016), kredi skorlaması yöntemlerinden lojistik regresyon, yapay sinir ağları ve hibrit modelleri Çin'deki 2012-2013 yıllarını kapsayan ve Küçük ve Orta Büyüklükteki İşletme (KOBI) portföyünden oluşturulan örneklem üzerinden değerlendirilmiştir. Çalışmada lojistik regresyon ve yapay sinir ağlarının çeşitli birleşimleri üzerinden 3 adet hibrit model oluşturulmuştur. Yapılan Doğruluk Oranı testi sonucunda en iyi performansı hibrit modellerden ikisinin sağladığı bulgusuna ulaşılmışır.

Demirbulut ve ark. (2017), çalışmalarında kredi skorlama yöntemlerini ele almış ve $\mathrm{K}$ en yakın komşu, C4.5 Ağacl, yapay sinir ağı, destek vektör makinesi, lojistik regresyon, probit regresyon, poisson regresyon ve genelleştirilmiş katkı modeli yöntemlerinin karşılaştııılması üzerinden analiz yapmışlardır. Algoritma sonuçları Area Under Curve (AUC) analizi ile değerlendirilmiş ve en yüksek performansı yapay sinir ağları modelinin verdiği bulgusuna ulaşılmışır.

Kangal (2017), çalışmasında kredi skorlaması yöntemlerinden lojistik regresyon, diskriminant analizi ve yapay sinir ağları modellerini karşılaştırmıştır. Çalışmada bireysel müşterilerin kredi kartılarını kapsayan fiktif verilerden oluşturulan örneklem üzerinden değerlendirme yapılmıştır. Yapılan Tip 1 ve Tip 2 hatası ve ROC (Receiver 
Operating Characteristic) eğrisi analizleri sonucunda yapay sinir ağları modelinin diğer modellere göre daha yüksek performans sergilediği bulgusuna ulaşılmıştır.

Literatürde yer alan çalışmalarda kredi skorlamasına ilişkin lojistik regresyon ve yapay sinir ağları kıyaslamaları mevcut olmakla birlikte, bu çalısmalar perakende portföyler üzerinden ele alınmıştır. Bu çalışmada ise kurumsal (non-retail) portföyler üzerinden kıyaslama yapılarak düşük temerrütlü portföydeki performansları analiz edilmiştir. Ayrıca çalışma 8 yıllık bir zaman dilimi kapsayan örneklemi ile de literatürdeki çalışmalardan farklılaşmaktadır.

\section{Ampirik Çalışma}

Büyük veri kitleleri üzerinden oluşturulan klasik temerrüt olasılığı model çıktıları kullanıcılar tarafından daha az sorgulamaya maruz kalırken, gözlem adedi kısıtlı olan portföyler için oluşturulan temerrüt olasılığı model çıktıları daha çok sorgulanabilmektedir. Bu kapsamda büyük veri üzerinde oldukça başarılı sonuçlar ürettiği bilinen yapay sinir ağı modellerinin sınırlı sayılabilecek gözlem setine sahip, göreceli olarak düşük temerrüt oranlı portföyler üzerindeki başarısının test edilmesi adına ampirik çalışma yapılmıştır. Çalışmada kurumsal segmentte yer alan imalat, hizmet ve ticaret sektörüne ait firmaların 2010-2017 yılları arasındaki finansal ve geri ödeme alışkanlıklarını yansıtabilecek 8 yıllık fiktif veri seti oluşturulmuştur. Bu veri üzerinden lojistik regresyon ve yapay sinir ağları modelleri kurularak firmaların 12 ay içerisinde temerrüde düşme ihtimalinin ölçülmesi hedeflenmiştir. Ardından modellerin örneklem dışı veri setindeki performansı incelenerek yapay sinir ağlarının anılan portföy üzerinde iyi ve kötü firmayı ayırt etmede ek bir katkı sağlayıp sağlamadığı yorumlanmıştır.

\subsection{Veri Seti}

Model çalışmasında örneklem olarak perakende olmayan kurumsal firmalar seçilmiştir. Bunun sebebi ise büyük veri üzerinde oldukça başarılı sonuçlar ürettiği bilinen yapay sinir ağı modellerinin sınırlı sayılabilecek gözlem setine sahip, göreceli olarak düşük temerrüt oranlı portföyler üzerindeki başarısının test 
edilmesidir. Örneklem dönemi 2010 ve 2017 yıllarını kapsayan 8 yıldan oluşmaktadır. Örneklem döneminin 2010'dan başlatılmasının sebebi ise verilerin geniş bir ekonomik dönemin etkilerini sağlamaktır. Veri türü sektörde kredi skorlama modellerinde kullanılan veri desenine benzer yapıda kurgulanmıştır. Bu sebeple lojistik regresyonda gözlem sayısı finansal verilerde 25.650, davranış verisinde ise 24.939, yapay sinir ağlarında ve lojistik regresyonda ise modül birleştirmesinden kaynaklı 21.922 olarak alınmıştır.

Örneklemde kullanılan veriler tek bir kaynaktan elde edilmemiştir. Finansal veri seti, sektörde kullanılan veri yapısı göz önünde bulundurularak, kurgusal olarak türetilmiştir. Finansal veri seti bilançodan ve gelir tablosundan türetildiği için veriler Türk Lirası olarak ele alınmıştır. Davranış veri seti ise memzuç, risk merkezi, Kredi Kayıt Bürosu (KKB) vb. dışsal veri sağlayıcılarından temin edilen ve müşterilerin piyasa alışkanlıklarını gösteren veri setinden oluşmaktadır.

Model geliştirme çalışmalarında kurumsal segment altında sınıflandırılan firmaların finansal yeterlilik seviyesini analiz etmek için kullanılan finansal tablo verileri ile firmaya ait geri ödeme alışkanlıklarını içeren memzuç, karşılıksız çek, protestolu senet, ihale yasağı ve vergi ödemelerine ait veriler büyük önem taşımaktadır. Bu kapsamda firmaların genel temerrüt oranlarını yakınsayacak veri setleri oluşturulmuştur.

Model geliştirme çalışmalarında ay sonları itibarıyla toplanan veriler üzerinden çalışmalar yürütülebileceği gibi, yıllar itibarıyla belirli dönemlere ait veriler üzerinden de model geliştirme çalışmaları yürütülebilmektedir. Bu kapsamda kurumsal firmaların, kurumlar vergisi mevzuatına göre mükelleflerin Nisan ayı sonuna kadar kesin vergi beyannamelerini yani bilançolarını verme hakkı bulunması ve firmaların büyük çoğunluğunun anılan tarihte kesin finansal tablolarını yayımlaması hususları göz önünde bulundurularak aylık veri seti oluşturulmuş ve her yılın 30 Nisan günü gözlem tarihi başlangıcı olarak belirlenmiştir.

Lojistik regresyon yönteminde sektör uygulamaları dikkate alınarak modüler yapı oluşturularak iki farklı modül üzerinden çalışma yapılmışır. Firmanın finansal göstergelerini içeren finansal modül ile ödeme alışkanlıkları gibi davranışsal 
bilgilerini kapsayan davranış modülü üzerinden ayrı ayrı modelleme yapılarak, iki modülün tekrardan regresyona sokulanarak nihai model regresyonu oluşturulmuştur. Yapay sinir ağlarında ise her iki modülün de bilgilerinden faydanılmış olmasına rağmen tek modül üzerinden çalışılmıştır. Aşağıda her iki modüle ilişkin bilgiler aşağıdaki başlıklarda yer almaktadır.

Model geliştirme çalışmalarında hedef değişkenin tanımlanması modelin temelini oluşturmaktadır. Temerrüde düşme olasılığı modellerinde firmaların 12 aylık temerrüt ihtimalinin belirlenmesi hedeflenmektedir. Bu nedenle oluşturulan veri seti üzerinden, ilgili gözlem tarihinden sonra 12 ay içerisinde, memzuç veri setinde sorunlu kredi riski bulunan firmalar temerrütlü firma, bildirimi olmayan firmalar da canlı firma olarak adlandırılmıştır. Sonrasında canlı ve temerrütlü firma özelliklerin daha net ayrışması adına; sorunlu riski olan firmalar sadece sorunlu riski olduğu dönemlerde, canlı firmalar ise veri setinde yer aldıkları tüm dönemlerde örnekleme dahil edilmiştir. Hedef değişkenin tanımlanması, bankacılık uygulamalarında en çok tercih edilen ve hedef değişkeni açıklayabilecek değişken listeleri aşağıda tanımlanmıştır.

Finansal veri setinde firmalara ait bilanço, gelir tablosu ve nakit akım tablolarında yer alan tüm bilgiyi kapsayacak ve firmaların mali yapılarını farklı açılardan ele alabilecek 6 ana başlıkta, 128 adet finansal değişken belirlenmiştir. Belirlenen değişkenler kategorize edilerek adetlerine aşağıda yer verilmiştir:

1- Borç karşılama: 27 değişken,

2- Gelişim: 9 değişken,

3- Finansal yapı: 39 değişken,

4- Likidite: 35 değişken,

5- Verimlilik: 5 değişken,

6- Kârlılık: 13 değişken.

Davranış veri setinde firmaların geri ödeme alışkanlıklarına ait bilginin yer aldığı veri setleri davranış veri seti olarak adlandırılmaktadır. Firmanın 12 ay içerisinde finansal kurumlardan birinde temerrüde düşme ihtimalini değerlendirilmiştir. Bu 
kapsamda çalışmada davranış verileri üzerinden geri ödeme alışkanlıklarını etkilediği öngörülen değişken listeleri oluşturulmuştur. Analiz edilen bilgiler genel olarak aşağıda özetlenmiş olup toplamda 152 adet finansal değişken hesaplanmıştır.

- Memzuç: Aylar itibarıyla, seçilen üst başlıklar bazında firmalara yönelik Risk Merkezine bildirilen limit, risk, temerrüt ve sorunlu risk bilgilerini içermektedir.

- Karşıllksız çek: Aylar itibarıyla, ilgili ay ve geçmiş 3, 6 ve 12 ay ile son 2 ve 3 yıla ait karşılıksız çıkan çek adet ve tutar bilgilerini içermektedir.

- Protestolu senet: Aylar itibarıyla, ilgili ay ve geçmiş 3, 6 ve 12 ay ile son 2 ve 3 yıla ait protesto edilen senet adet ve tutar bilgilerini içermektedir.

- İcra: Aylar itibarıyla, geçmiş 1, 2 ve 3 yıla ait firmaların borçlu olarak yer aldığı icra tutarı bilgilerini içermektedir.

- Ihale Yasağı: Aylar itibarıyla, firma adına konulan ihale yasağı açıış̧, kapanış ve yasak koyan kurum bilgilerini içermektedir.

- Vergi Borcu: Aylar itibarıyla, vergi idaresi tarafından açılanan, borçlusu firma olan borç dönemi ve borç tutarı bilgilerini içermektedir.

Söz konusu değişkenler, aşağıda detaylı olarak açıklanan değişken tedavileri yoluyla düzenlenmiş ve tek değişkenli analizlere tabi tutularak değişken sayısı hedef değişkeni açıklama gücüne göre azaltılmıştır.

\subsubsection{Değişken Tedavileri}

Veri setlerinde uç değerler, boş kayıtlar ve 0/0-N/0 gibi hesaplanamayan değerler yer alabilmektedir. Bu kapsamda örneklemde yer alan her bir firma özelinde değişkenler hesaplandıktan sonra, değişkenlerin hesaplanamadığı durumların yönetilmesi, uç ve ekstrem değerlerin düzeltilmesi ve kabul edilebilir sınırlarda yer alan kayıp değişkenlerin doldurulması işlemine geçilmiştir. Burada temel amaç, regresyon tahminlerinin daha tutarlı ve genel kitleyi yansıtır özellikte olmasını sağlamak olduğundan değişken özelinde düzeltmeler, aşağıdaki kriterler baz alınarak yapılmıştır:

-Uç değer doldurmaları: Regresyon modellerinde örneklem içerisinde yer alan her bir değer model üzerinde eşit etki etmektedir. Bu nedenle genel kitleden 
ayrışan uç değerler genel kitlenin yapısını değiştirebilir. Kitlenin genel yapısının sağlıklı bir şekilde yansıtılması adına, her bir değişken kendi içerisinde yüzdelik dilimlere ayrılmış, uç değerler (2. ve 98. yüzdelik dilimlerin ötesinde yer alan değerler) 2 ve 98 yüzdelik dilim değerlerine çekilmiştir.

-Hesaplanamayan değişken düzeltmeleri: Matematiksel olarak hesaplama yapılamaması durumunda ilgili değişken regresyonda boş kayıt olarak yer almaktadır. Ancak hesaplanamayan değişkenler yapıları kapsamında bilgi içermektedir. Bu nedenle çalışmada $0 / 0$ ve N/O gibi tanımsız sonuçlanan değişkenler yapılarına istinaden nötr değerler atanarak düzeltmeler yapılmıştır.

Modül bazında her bir değişken için 2. ve 98. yüzdelik dilimlere denk gelen değerler, nötr değerler, ve canlı / temerrütlü kayıtların kayıp oranları aşağıdaki tablolarda paylaşılmıştır. Tablodan da görüldüğü üzere söz konusu oranlar modelin başarısını etkilemeyecek kadar düşük seviyededir.

Tablo 1: Finansal Modül Değişkenleri P2, P98, Nötr Değerleri ve Kayıp Oranları

\begin{tabular}{|l|c|c|c|c|c|}
\hline \multicolumn{7}{|c|}{ Değişken } & P2 & P98 & Nötr & $\begin{array}{c}\text { Temerrüde } \\
\text { Düşmemiş Firmaların } \\
\text { Kayıp Oranı }\end{array}$ & $\begin{array}{c}\text { Temerrütlülerin } \\
\text { Kayıp Oranı }\end{array}$ \\
\hline V1 & 4,70999685 & $-0,33720161$ & 92,98400772 & 0,047 & 0,007 \\
\hline V2 & 9,731342235 & $-0,24594968$ & 212,2437744 & 0,003 & 0,000 \\
\hline V3 & 0,722446451 & 0,145794026 & 1,078965179 & 0 & 0 \\
\hline V4 & 4,613068893 & $-1,6449458$ & 50,21907101 & 0,051 & 0,025 \\
\hline V5 & 0,748481893 & $-0,43468658$ & 4,787615413 & 0,110 & 0,113 \\
\hline V6 & 0,013494563 & $-0,17991912$ & 0,192866779 & 0,041 & 0,035 \\
\hline V7 & 0,050167676 & 0,000889173 & 0,280851727 & 0 & 0 \\
\hline V8 & 0,422106145 & 0,031835447 & 1,276001597 & 0,051 & 0,043 \\
\hline V9 & 0,121927098 & 0,004399832 & 0,398067864 & 0,051 & 0,048 \\
\hline V10 & 1,937821672 & $-0,55461545$ & 20,19292937 & 0,036 & 0,031 \\
\hline V11 & $-1,05032778$ & $-5,54653224$ & 0,384280148 & 0 & 0 \\
\hline V12 & 0,234897573 & 0,003243101 & 0,733730505 & 0 & 0 \\
\hline V13 & $-0,06888598$ & $-2,13212665$ & 1,230340592 & 0,022 & 0,020 \\
\hline V14 & 0,460418535 & 0,000160371 & 0,910004142 & 0 & 0 \\
\hline V15 & 25,20168138 & 1,802984746 & 324,1664424 & 0,0518 & 0,0680 \\
\hline V16 & 0,161163898 & 0,001991158 & 0,546246505 & 0,0183 & 0,0219 \\
\hline V17 & 3,771480648 & $-21,0700671$ & 84,99095604 & 0,023 & 0,027 \\
\hline V18 & 10,0085637 & 1,180401679 & 88,55517371 & 0,0233 & 0,0293 \\
\hline
\end{tabular}

Not: Tablo yazar tarafından hazırlanmıştır. 
Tablo 2: Davranış Modülü Değişkenleri P2, P98, Nötr Değerleri ve Kayıp Oranları

\begin{tabular}{|l|c|c|c|c|c|}
\hline \multicolumn{7}{|c|}{ Değişken } & P2 & P98 & Nötr & $\begin{array}{c}\text { Temerrüde } \\
\text { Düşmemiş Firmaların } \\
\text { Kayıp Oranı }\end{array}$ & $\begin{array}{c}\text { Temerrütlülerin } \\
\text { Kayıp Oranı }\end{array}$ \\
\hline V1- $d$ & 0,0000 & 27.005 .623 & $1.934 .842,585$ & 0 & 0 \\
\hline V2- $d$ & 0,0000 & 0,0000 & 0,010925147 & 0 & 0 \\
\hline V3- $d$ & 0,0000 & 1,0000 & 0,16851018 & 0 & 0 \\
\hline V4- $d$ & 0,0000 & 1,0000 & 0,221073554 & 0 & 0 \\
\hline V5- $d$ & 0,0174 & 0,7871 & 0,37230141 & 0,0001 & 0 \\
\hline V6- $d$ & 0,0000 & 36,0000 & 20,28397786 & 0 & 0 \\
\hline V7-d & 0,0000 & 1,1407 & 0,052124357 & 0 & 0 \\
\hline V8- $d$ & 5,0000 & 32,0000 & 16,93961763 & 0 & 0 \\
\hline V9- $d$ & 0,0000 & 0,5184 & 0,02941816 & 0 & 0 \\
\hline V10- $d$ & 0,0000 & 24,0000 & 5,812931755 & 0 & 0 \\
\hline V11- $d$ & 0,0000 & 1,0000 & 0,49727481 & 0 & 0 \\
\hline
\end{tabular}

Not: Tablo yazar tarafından hazırlanmıştır.

\subsubsection{Tek Değişkenli Analizler}

Her ne kadar çalışma başında toplamda davranış bilgileri için 293 değişken ve finansal bilgiler için 160 adet değişken üretilmiş olsa da söz konusu değişkenlerin, hedef değişken üzerindeki etkileri değişmektedir. Bu kapsamda model geliştirim aşamasına ilerlemeden önce tek değişkenli analiz çalışmaları ile canlı/temerrütlü durumunu açılamada mantıksal ve istatiksel açıdan nispeten daha etkili olan değişkenler tespit edilmeye çalışılmıştır. Uzun değişken listesinden kısa değişken listesine geçilmesi aşamasında sırasıyla yapılan analizlere aşağıda yer verilmiştir:

-Accuracy Ratio (Doğruluk Oranı): Doğruluk Oranı (AR), sınıflandırma modellerinde Ayrım Gücünün özet bir niceliksel ölçüsüdür. AR ölçüsü, "mükemmel" ayırt edici modele kıyasla, incelenen modelin güç eğrisinin üstünde ve altında kalan alanının oranını ifade eder. Hedef değişkeni açıklamada AR değeri \%10 altında olan değişkenler elenerek modelleme aşamasında göreceli olarak daha etkili olan değişkenlerin kısa değişken listesinde yer alması amaçlanmıştır. 
-Temerrüt eğrisi: Değişkenin değeri ile temerrüt oranı arasındaki ilişki grafikler yardımıyla incelenmiş, ekonomik beklenti ile uyumlu hareket etmeyen değişkenler elenerek kısa listede yer almamıştır.

-Kayıp değer oranı: Çalışmada her bir değişkenin doluluk oranları hesaplanarak tüm örneklemin \%15'inden daha büyük bir oranda değer ataması olmayan değişkenler değişken listesinden elenmiştir. Belirlenen asgari sınıın (\%15) altında kayıp verisi olan değişkenler nihai sonucu etkilememesi adına "nötr değer" ile doldurulmuştur. Nötr değer, hesaplamaya konu değişkenin canlı firmalardan aldığı değerlerin ortalaması ile sorunlu firmalardan aldığı değerlerin ortalamasının ortalaması alınarak hesaplanmaktadır.

-Korelasyon analizi: Yüksek korelasyon içeren değişkenlerin model içerisinde yer alması çoklu doğrusal bağlantı problemine ve dolayısıyla değişken katsayılarının yanlış tahminlenmesine ve model çıktılarının doğru yorumlanamamasına sebebiyet vermektedir. Bu kapsamda yukarıda bahsedilen analizler sonrasında kalan bağımsız değişkenler için korelasyon matrisi oluşturulmuştur. Matriste \%50 ve üzerinde korelasyon bulunan değişkenlerden, hedef değişkeni açıklama gücü en yüksek olan değişken dışındaki bağımsız değişkenler elenerek nihai kısa değişken listesine ulaşılmıştır. Modüller için seçilen kısa liste değişkenleri aşağıdaki tablolarda yer almaktadır:

Tablo 3: Finansal Modül Kısa Liste Değişkenleri

\begin{tabular}{|l|l|l|l|}
\hline Değişkenler & Alan Adı & Değişken Adı & Açıklama \\
\hline V1 & $\begin{array}{l}\text { Finansal } \\
\text { Yapı }\end{array}$ & $\begin{array}{l}\text { Kısa vadeli borçlar/ } \\
\text { Özkaynak }\end{array}$ & $\begin{array}{l}\text { İşletmenin özkaynakları ile kısa vadeli borçlarını } \\
\text { ne ölçüde karşılanabildiğini ifade eden orandır. }\end{array}$ \\
\hline V2 & $\begin{array}{l}\text { Finansal } \\
\text { Yapı }\end{array}$ & $\begin{array}{l}\text { Özkaynak/ } \\
\text { ödenmemiş } \\
\text { sermaye }\end{array}$ & $\begin{array}{l}\text { Işlletmenin toplam özkaynakları içerisinde ki } \\
\text { ödenmemiş sermaye miktarını ifade eden orandır. }\end{array}$ \\
\hline V3 & $\begin{array}{l}\text { Finansal } \\
\text { Yapı }\end{array}$ & Net borçlar & $\begin{array}{l}\text { İşletmenin toplam varlıkları içerisinde ki net } \\
\text { borçlarını ifade eden orandır. }\end{array}$ \\
\hline V4 & $\begin{array}{l}\text { Karç } \\
\text { Karşlama }\end{array}$ & $\begin{array}{l}\text { FVAÖK/Finansman } \\
\text { Giderleri }\end{array}$ & $\begin{array}{l}\text { Elde edilen finansal maliyetler, vergiler ve } \\
\text { amortisman gideri öncesi oluşan satış kârı ile } \\
\text { kredi faizin kaç kez ödenebileceğini gösterir. }\end{array}$ \\
\hline
\end{tabular}




\begin{tabular}{|c|c|c|c|}
\hline V5 & $\begin{array}{l}\text { Borç } \\
\text { Karşılama }\end{array}$ & $\begin{array}{l}\text { Net finansman } \\
\text { geliri/FVAÖK }\end{array}$ & $\begin{array}{l}\text { Firmanın net finansman gelirinin, finansal } \\
\text { maliyetler, vergiler, yıpranma payı ve amortisman } \\
\text { giderleri gibi parametreler hesaba katılmadan elde } \\
\text { ettiği gelir. }\end{array}$ \\
\hline V6 & Kârlılık & $\begin{array}{l}\text { Dönem geliri/net } \\
\text { satışlar }\end{array}$ & Net satış karlılığını gösterir. \\
\hline V7 & Likidite & $\begin{array}{l}\text { Nakit ve benzeri/ } \\
\text { varlıklar }\end{array}$ & $\begin{array}{l}\text { İşletmenin nakde dönüşüm kabiliyeti yüksek } \\
\text { varlıklarının toplam içindeki oranını gösterir. }\end{array}$ \\
\hline V8 & $\begin{array}{l}\text { Borç } \\
\text { Karşılama }\end{array}$ & $\begin{array}{l}\text { Borç karşılama } \\
\text { oranı }\end{array}$ & $\begin{array}{l}\text { Borcun anapara taksiti ve faiz toplamının } \\
\text { işletmenin o dönemde faaliyetleri sonucunda } \\
\text { yaratılan fon kaynakları ile borç taksitlerini kaç } \\
\text { defa karşılayacak gelir elde ettiğini gösterir. }\end{array}$ \\
\hline V9 & Kârlılık & Brüt kar/net satışlar & $\begin{array}{l}\text { Brüt satış karlılığı olup, firmanın satış maliyetleri } \\
\text { düşmeden elde ettiği karı gösterir. }\end{array}$ \\
\hline V10 & $\begin{array}{l}\text { Finansal } \\
\text { Yapı }\end{array}$ & $\begin{array}{l}\text { Özkaynak/duran } \\
\text { varlıklar }\end{array}$ & $\begin{array}{l}\text { İşletmenin duran varlıkları özvarlıklarıyla karşılama } \\
\text { oranıdır. }\end{array}$ \\
\hline V11 & $\begin{array}{l}\text { Borç } \\
\text { Karşılama }\end{array}$ & $\begin{array}{l}\text { Finansal } \\
\text { aktivitelerden elde } \\
\text { edilen kar veya } \\
\text { zarar/FVAÖK }\end{array}$ & $\begin{array}{l}\text { İşletmenin faiz ve vergi öncesi karı içinde finansal } \\
\text { aktivitelerden elde ettiği kar veya zararın ne kadar } \\
\text { olduğunu gösteren orandır. }\end{array}$ \\
\hline V12 & $\begin{array}{l}\text { Finansal } \\
\text { Yapı }\end{array}$ & $\begin{array}{l}\text { Duran varlıklar/ } \\
\text { varlıklar }\end{array}$ & $\begin{array}{l}\text { İşletmenin faaliyet döneminde toplam varlıkları } \\
\text { içerisinde ki nakde çevirmek istemediği varlıkların } \\
\text { oranını gösterir. }\end{array}$ \\
\hline V13 & Kârlılık & $\begin{array}{l}\text { Dönem geliri/ } \\
\text { özkaynaklar }\end{array}$ & $\begin{array}{l}\text { Özkaynak karlıığını, vergi öncesi karı kullanarak } \\
\text { ölçen orandır. }\end{array}$ \\
\hline V14 & $\begin{array}{l}\text { Finansal } \\
\text { Yapı }\end{array}$ & $\begin{array}{l}\text { Kısa vadeli krediler/ } \\
\text { kısa vadeli borçlar }\end{array}$ & $\begin{array}{l}\text { İşletmenin kısa vadeli yükümlülüklerinin ne } \\
\text { kadarının mali borçlardan kaynaklandığını } \\
\text { gösteren orandır. }\end{array}$ \\
\hline V15 & Verimlilik & $\begin{array}{l}\text { Üretim değeri/ } \\
\text { stoklar }\end{array}$ & $\begin{array}{l}\text { İşletmenin satışları ile elde kalan stoklarının tüm } \\
\text { stok içerisindeki verimliliğini gösterir. }\end{array}$ \\
\hline V16 & Likidite & Stoklar/brüt satışlar & $\begin{array}{l}\text { İşletmenin dönem içerisindeki stoklarının brüt } \\
\text { satışa oranıdır. }\end{array}$ \\
\hline V17 & Likidite & $\begin{array}{l}\text { Esas faaliyetten } \\
\text { yaratılan nakit/ } \\
\text { finansman gideri }\end{array}$ & $\begin{array}{l}\text { İşletmenin esas faaliyetlerinden kaynaklanan } \\
\text { nakit akımının, finansman giderinin ne kadarını } \\
\text { karşıladığını göstermektedir. <0 ise nakit açığı } \\
\text { veriyor demektir. >0 ise finansman giderinin ne } \\
\text { kadarını karşıladığına bakıır. }\end{array}$ \\
\hline V18 & Likidite & Alacak devir hızı & $\begin{array}{l}\text { Firma alacaklarının kaç defa tahsil edildiğini } \\
\text { göstermektedir. İşletmenin varlıklarının ne kadar } \\
\text { verimli kullanıldığına dair önemli bir göstergedir. }\end{array}$ \\
\hline
\end{tabular}

Not: Tablo yazar tarafından hazırlanmıştır. 


\begin{tabular}{|l|l|}
\hline \multicolumn{2}{|c|}{ Tablo 4: Davranış Modülü Kısa Liste Değişkenleri } \\
\hline Değişken & Açıklama \\
\hline V1 & Firmanın son 36 aydaki ödenmemiş çek ve senetlerinin toplam tutarıdır. \\
\hline V2 & Firmanın son yılda ihale yasağı tarihi dolu ise "1" değerini alır (Flag değişken). \\
\hline V3 & $\begin{array}{l}\text { Firmanın son 12 aydaki ödenmemiş çeklerinin sayısı 0'dan büyükse "1" değerini alır } \\
\text { (Flag değişken). }\end{array}$ \\
\hline V4 & Firmanın son aydaki aksama tutarının 0'dan büyük olmasıdır. \\
\hline V5 & Firmanın son 12 aydaki toplam riskinin, son 12 aydaki toplam limitine oranıdır. \\
\hline V6 & Son gecikme ya da sorunlu risk (1+3)'ten bu yana geçen süredir. \\
\hline V7 & $\begin{array}{l}\text { Firmanın son 12 aydaki problemli nakdi risk tutarı ("1" ve "3" ile başlayanlar), son 12 } \\
\text { aydaki problemli faktoring risk tutarı, son 12 aydaki problemli leasing risk tutarı, son } \\
\text { 12 aydaki problemli gayrinakdi risk tutarı ve son 12 aydaki gecikme tutarı toplamının } \\
\text { maksimumunun net satışlardaki payıdır. }\end{array}$ \\
\hline V8 & Firmanın çalıştığı finansal kurum sayısıdır. \\
\hline V9 & Firmanın son 3 yıl icra tutarı / son yıl cirosudur. \\
\hline V10 & Firmanın maksimum riskinin oluştuğu dönemden bugüne geçen ay sayısıdır. \\
\hline V11 & Firmanın son 2 yılda icra kaydı varsa "1" değerini alır (Flag değişken). \\
\hline
\end{tabular}

Not: Tablo yazar tarafından hazırlanmıştır.

\subsection{Metodoloji}

Model tahminlemesi yapılmadan önce değişkenler üzerinde analizler gerçekleştirilmiştir. Öncelikle değişkenlerdeki boş kayıtlar ve tanımsız değerlerin ${ }^{1}$ doldurulması ve uç değerlerin düzeltilmesi için değişken tedavileri uygulanmıştır. Aşağıda değişkenler üzerinde gerçekleştirilen tedaviler detaylandırılmıştır. Değişken tedavilerinden sonra uzun değişken listesinde yer alan değişkenlerden, hangilerinin modele dahil edileceğinin belirlenmesi için tek değişkenli analizler gerçekleştirilerek kısa liste oluşturulmuştur. Daha sonra kısa listede kalan değişkenler lojistik regresyon ve yapay sinir ağları yöntemleri ile modellenmiştir.

Lojistik regresyon yönteminde, finansal ve davranış verilerinin ayrı analiz edilebilmesi için modüler yapı oluşturularak finansal modül ve davranış modülü ayrı ayrı tahminlenmiştir. Yapay sinir ağları yönteminde ise lojistik regresyon çalışmasından farklı olarak modüler yapı kullanılmamış, davranış ve finansal modüllerin geliştirilmesinde kullanılan kısa değişken listeleri birleştirilerek tek bir 
değişken listesi üzerinden yapay sinir ağları modeli kurulmuştur. Yapay sinir ağları modelinde çok katmanlı algılayıcılar ve ileri beslemeli ağlar tercih edilmiştir.

\subsection{Model Tahminleri}

Model tahminlerinde iki farklı yöntem ele alınmış ve model performansları üzerinden bu yöntemler kıyaslanmıştır. Modellerin performans analizi için geliştirme örneklemi ve örneklem dışı veri seti üzerinden Gini değeri hesaplanmıştır.

\subsubsection{Lojistik Regresyon Analizi}

Kısa bağımsız değişken listelerinin oluşturulması üzerine hedef değişkenin tahminlenmesi aşamasına geçilmiştir. Finansal ve davranış verilerinin ayrı analiz edilebilmesi için modüler yapı oluşturularak finansal modül ve davranış modülü ayrı ayrı tahminlenmiştir. Hem finansal modül hem de davranış modülü kısa liste değişkenleri dolu olan kitle üzerinden modelleme örneklemi tespit edilmiş, \%5 hata payıyla (\%95 güven düzeyinde) forward stepwise (değişken seçimi regresyona bırakılarak ileri yönlü adımsal) regresyon modelleme yöntemi kullanılarak modül fonksiyonları tahminlenmiştir. Forward stepwise metodu temel olarak potansiyel değişkenler ile sınama modeli oluşturarak, katsayıların istatistiksel anlamlılığını, $\mathrm{F}$ testini ve modelin adım adım eklenen değişkenler sonucunda elde edilen determinasyon katsayısını kontrol ederek eleme işlemi gerçekleştirir. (Keskinkılıç, 2008). Her bir modül fonksiyonunda, herhangi bir firmanın teorik olarak temerrüt olasılığı \%0 olamayacağından hareketle, sabit terime yer verilmiştir.

Modellemeye konu olacak veri seti, finansal modül için 25.082 canlı ve 568 temerrütlü, toplam 25.650 firma içeriyorken, davranış modülü tarafında ise 24.216 canlı ve 723 temerrütlü olmak üzere 24.939 firma kaydı içermektedir. Aşağıda modüler yapıya ilişkin detaylı bilgilendirme mevcuttur.

Tahminlenen modül fonksiyonunda yer alan değişkenlere ait katsayıların yönleri mantıksal sınamadan geçirilmiş olup ekonomik beklentinin aksi yönünde herhangi bir katsayı ataması olmaması nedeniyle regresyon çalışması yenilenmemiştir. 


\subsubsection{Finansal Modülün Tahminlenmesi}

Nihai kısa liste değişkenlerinin seçilmesiyle finansal modülün tahminlemesine geçilmiştir. Tahminleme işleminde hedef değişken olarak temerrüt - canlı değişkeni, açıklayıcı değişken olarak da finansal kısa değiş̧ken listesinde yer alan değişkenler alınmış ve stepwise lojistik regresyon yöntemi kullanılarak (\%95 güven düzeyinde) finansal modül regresyonu oluşturulmuştur. Finansal modüle ilişkin regresyon aşağıdaki tabloda yer almaktadır:

Tablo 5: Finansal Modül-Model değişkenleri

\begin{tabular}{|c|c|c|c|c|c|c|}
\hline Değişken & Açıklama & Katsayı & $\begin{array}{c}\text { Standart } \\
\text { Hata }\end{array}$ & $\begin{array}{c}\text { Wald } \\
\text { Ki-Kare } \\
\text { İstatistiği }\end{array}$ & $\begin{array}{l}\text { Pr }>\mathrm{Ki}- \\
\text { Kare }\end{array}$ & $\operatorname{Exp}(B)$ \\
\hline V1 & $\begin{array}{c}\text { Kısa vadeli borçlar/ } \\
\text { Özkaynak }\end{array}$ & 1,293 & 0,223 & 33,689 & 0 & 3,644 \\
\hline V3 & Net borçlar & 1,049 & 0,189 & 30,835 & 0 & 2,855 \\
\hline V4 & $\begin{array}{c}\text { FVAÖK/Finansal } \\
\text { Harcamalar }\end{array}$ & $-1,157$ & 0,438 & 6,981 & 0,008 & 0,314 \\
\hline V7 & $\begin{array}{l}\text { Nakit ve benzeri } \\
\text { varlıklar/ Toplam } \\
\text { varlıklar }\end{array}$ & $-0,203$ & 0,036 & 32,301 & 0 & 0,816 \\
\hline V9 & Brüt kar/net satışlar & $-0,212$ & 0,049 & 18,549 & 0 & 0,809 \\
\hline V15 & Üretim değeri/stoklar & $-0,278$ & 0,048 & 33,605 & 0 & 0,757 \\
\hline Constant & & $-3,924$ & 0,246 & 254,81 & 0 & 0,02 \\
\hline
\end{tabular}

Not: Tablo yazar tarafından hazırlanmıştır.

Fonksiyonda yer alan değişkenlere ait katsayıların yönleri incelendiğinde tüm değişkenlerin ekonomik beklenti ile uyumlu hareket ettiği görülmüştür.

Model tarafından Finansal Modülde forward stepwise yöntemiyle \%95 güven aralığında seçilen değişkenlere ilişkin stepwise adımları özet tablosu aşağıda paylaşılmıştır: 
Şekil 2: Finansal Modül Değişken Seçim Adım Özetleri

Step Summary

\begin{tabular}{|c|c|c|c|c|c|c|c|c|}
\hline \multirow[b]{2}{*}{ Step } & \multicolumn{3}{|c|}{ Improvement } & \multicolumn{3}{|c|}{ Model } & \multirow{2}{*}{$\begin{array}{c}\text { Correct Class } \\
\%\end{array}$} & \multirow[b]{2}{*}{ Variable } \\
\hline & Chi-square & $d f$ & Sig. & Chi-square & df & Sig. & & \\
\hline 1 & 103,955 & 1 &, 000 & 103,955 & 1 & 000 & $97,6 \%$ & $\mathrm{IN}: \mathrm{V} 1$ \\
\hline 2 & 87,069 & 1 &, 000 & 191,024 & 2 &, 000 & $97,6 \%$ & IN: V7 \\
\hline 3 & 64,562 & 1 &, 000 & 255,586 & 3 &, 000 & $97,6 \%$ & IN: V3 \\
\hline 4 & 28,749 & 1 &, 000 & 284,335 & 4 &, 000 & $97,6 \%$ & IN: V15 \\
\hline 5 & 20,106 & 1 &, 000 & 304,442 & 5 &, 000 & $97,6 \%$ & IN: V9 \\
\hline 6 & 8,787 & 1 &, 003 & 313,228 & 6 &, 000 & $97,6 \%$ & IN: V4 \\
\hline
\end{tabular}

Not: Şekil yazar tarafından hazırlanmıştır.

Model tarafından seçilen değişkenlerin model içerisindeki önem seviyelerine ilişkin analizler yapılmış olup firmanın net borç tutarı ve işletmenin toplam varlıkları içerisindeki nakit ve benzeri kalemlerin ağırlı̆̆ı firmanın 12 ay içerisindeki batma olasılığını açıklamada oldukça anlamlıdır.

Masaryk Üniversitesin'den Martin Řezac ve František Řezac (2011) yılında yayınladıkları çalışmalarında kredi riski modellerinin performansının ölçülmesinde en etkili yöntemlerden birinin Gini endeksi olduğunu belirtmişlerdir. Söz konusu çalışmaya istinaden elde edilen modelin iyi ve kötü firmayı ayırt etme konusundaki performansını analiz etmek için modellerin Gini değeri hesaplanmıştır. Modelin geliştirme örneklemi üzerinde gösterdiği başarı, modellemeye konu olmayan farklı bir veri seti üzerinde test ederek modelin performansı analiz edilmiştir. Bu kapsamda modelin örneklem dışı veri seti üzerindeki performansına ait Gini değeri hesaplanmıştır. Model geliştirme örneklemi üzerinde \%45,6 Gini değerine sahip olan modelin örneklem dışı veri seti üzerindeki performansı bir miktar düşüş göstererek \%37,3 olarak hesaplanmıştır. Her ne kadar finansal modülün örneklem dışı verileri üzerindeki başarısı değişiklik göstermiş olsa da modüllerin entegrasyonu sonucunda elde edilecek nihai modelin örneklem dışı verileri üzerindeki performansı, genel uygulamaların karar verme sürecinde daha etkili olmaktadır.

\subsubsection{Davranış Modülünün Tahminlenmesi}

Davranış modülü için nihai kısa liste değişkenlerinin seçilmesiyle davranış modülünün tahminlemesine geçilmiştir. Tahminleme işleminde hedef değişken 
olarak temerrüt - canlı değişkeni, açıklayıcı değişken olarak davranış modülü kısa değişken listesinde yer alan değişkenler üzerinden stepwise lojistik regresyon yöntemi kullanılarak (\%95 güven düzeyinde) finansal modül oluşturulmuştur. Nihai davranış modülüne ait sonuç aşağıdaki tabloda yer almaktadır:

Tablo 6: Davranış Modülü-Model Değişkenleri

\begin{tabular}{|c|c|c|c|c|c|c|}
\hline Değişken & Açıklama & Katsayı & $\begin{array}{c}\text { Standart } \\
\text { Hata }\end{array}$ & $\begin{array}{c}\text { Wald } \\
\text { Ki-Kare } \\
\text { İstatistiği }\end{array}$ & $\begin{array}{c}\mathrm{Pr}>\mathrm{Ki}- \\
\quad \text { Kare }\end{array}$ & $\operatorname{Exp}(B)$ \\
\hline V5-d & $\begin{array}{l}\text { Firmanın son } 12 \text { aydaki } \\
\text { toplam riskinin, son } 12 \\
\text { aydaki toplam limitine } \\
\text { oranı }\end{array}$ & 1,011 & 0,089 & 127,913 & 0 & 2,749 \\
\hline V6-d & $\begin{array}{l}\text { Son gecikme ya da sorunlu } \\
\text { riskten bu yana geçen süre }\end{array}$ & $-1,299$ & 0,107 & 148,448 & 0 & 0,273 \\
\hline V7-d & \begin{tabular}{|l} 
Firmanın son 12 aydaki \\
problemli nakdi risk tutarı \\
son 12 aydaki problemli \\
faktoring risk tutarı, son 12 \\
aydaki problemli leasing \\
risk tutarı, son 12 aydaki \\
problemli gayrinakdi risk \\
tutarı ve son 12 aydaki \\
gecikme tutarı toplamının \\
maksimumunun net \\
satışlardaki payı \\
\end{tabular} & 1,756 & 0,319 & 30,382 & 0 & 5,788 \\
\hline V8-d & \begin{tabular}{|l|} 
Firmanın çalıştığı finansal \\
kurum sayısı
\end{tabular} & 0,859 & 0,116 & 54,584 & 0 & 2,361 \\
\hline V9-d & $\begin{array}{l}\text { Son } 3 \text { yıl icra tutarı / son } \\
\text { yıl ciro }\end{array}$ & 1,699 & 0,238 & 51,116 & 0 & 5,466 \\
\hline V10-d & $\begin{array}{l}\text { Firmanın maksimum } \\
\text { riskinin oluştuğu } \\
\text { dönemden bugüne geçen } \\
\text { ay sayısı }\end{array}$ & $-0,974$ & 0,284 & 11,791 & 0,001 & 0,378 \\
\hline Constant & & $-3,57$ & 0,36 & 98,079 & 0 & 0,028 \\
\hline
\end{tabular}

Not: Tablo yazar tarafından hazırlanmıştır.

Model tarafından Davranış Modülünde forward stepwise yöntemiyle \%95 güven aralı̆̆ında seçilen değişkenlere ilişkin Stepwise adımları özet tablosu aşağıda paylaşılmıştır: 
Şekil 3: Davranış Modülü Değişken Seçim Adım Özetleri Step Summary

\begin{tabular}{|c|c|c|c|c|c|c|c|c|}
\hline \multirow[b]{2}{*}{ Step } & \multicolumn{3}{|c|}{ Improvement } & \multicolumn{3}{|c|}{ Model } & \multirow{2}{*}{$\begin{array}{c}\text { Correct Class } \\
\% \\
\end{array}$} & \multirow[b]{2}{*}{ Variable } \\
\hline & Chi-square & df & Sig. & Chi-square & df & Sig. & & \\
\hline 1 & 408,480 & 1 & .000 & 408,480 & 1 & .000 & $96,8 \%$ & IN: V6-d \\
\hline 2 & 207,984 & 1 &, 000 & 616,464 & 2 &, 000 & $96,8 \%$ & IN: V5-d \\
\hline 3 & 58,850 & 1 &, 000 & 675,314 & 3 &, 000 & $96,8 \%$ & IN: V9-d \\
\hline 4 & 55,514 & 1 &, 000 & 730,829 & 4 &, 000 & $96,8 \%$ & IN: V8-d \\
\hline 5 & 24,739 & 1 &, 000 & 755,567 & 5 &, 000 & $96,8 \%$ & IN: V7-d \\
\hline 6 & 12,876 & 1 &, 000 & 768,444 & 6 &, 000 & $96,8 \%$ & IN: V10-d \\
\hline
\end{tabular}

Not: Şekil yazar tarafından hazırlanmıştır.

Fonksiyonda yer alan değişkenlere ait katsayıların yönleri incelendiğinde tüm değişkenlerin beklenti ile aynı yönde hareket ettiği görülmüştür. Model değişkenlerinin önem seviyeleri incelendiğinde firmanın finansal sistemdeki toplam riskinin toplam limitine oranı ve firmanın son gecikmeli ya da sorunlu kredi ödemesinden gözlem tarihine kadar geçen süreyi kapsayan değişken firmanın 12 ay içerisindeki batma olasılığını açıklamada oldukça anlamlıdır.

Elde edilen modelin iyi ve kötü firmayı ayırt etme konusundaki performansını analiz etmek için modelin Gini değeri ve modelin örneklem dışı verisi üzerindeki performansına ait Gini değeri hesaplanmıştır. Model geliştirme örneklemi üzerinde \%57,9 Gini değerine sahip olan modelin örneklem dışı verisi üzerindeki performansı yükselmiştir (Gini değeri \%67,9 olarak hesaplanmıştır). Finansal modül bölümünde de belirtildiği üzere karar süreçlerinde nihai modelin performansı daha etkili olmaktadır.

\subsubsection{Modüllerin Birleştirilmesi}

Finansal ve davranış modüllerinin ürettiği sonuçlar \%5 hata payıyla enter regresyon yöntemi kullanılarak birleştirilmiş ve nihai modele ulaşılmıştır. Modül sonuçları aşağıda gösterilmiştir: 
Tablo 7: Modül Birleştirilmesi-Model Değişkenleri

\begin{tabular}{|l|c|c|c|c|c|c|}
\hline Modül & Açıklama & Katsayı & $\begin{array}{c}\text { Standart } \\
\text { Hata }\end{array}$ & $\begin{array}{c}\text { Wald } \\
\text { Ki-Kare } \\
\text { İstatistiği }\end{array}$ & Pr > Ki-Kare & Exp(B) \\
\hline $\begin{array}{l}\text { \$LP-1- } \\
\text { finansal }\end{array}$ & $\begin{array}{c}\text { Finansal } \\
\text { Modül }\end{array}$ & 17,947 & 1,486 & 145,904 & 0 & 62.263 .718 \\
\hline \$LP-1-dıssal & $\begin{array}{c}\text { Davranış } \\
\text { Modülü }\end{array}$ & 10,298 & 0,679 & 230,202 & 0 & $29.668,27$ \\
\hline Constant & Sabit & $-4,819$ & 0,086 & 3145,622 & 0 & 0,008 \\
\hline
\end{tabular}

Not: Tablo yazar tarafından hazırlanmıştır.

Modüllerin birleşimi sonrasında modüllerin önem seviyesini gösteren grafiğe aşağıda yer verilmiş olup davranış modülünün temerrüt olasılığını açıklamada göreceli olarak finansal modülden daha etkili olduğu görülmüştür.

\section{Şekil 4: Modül birleştirmesi- Değişkenlerin Model İçerisindeki Önem Seviyeleri}

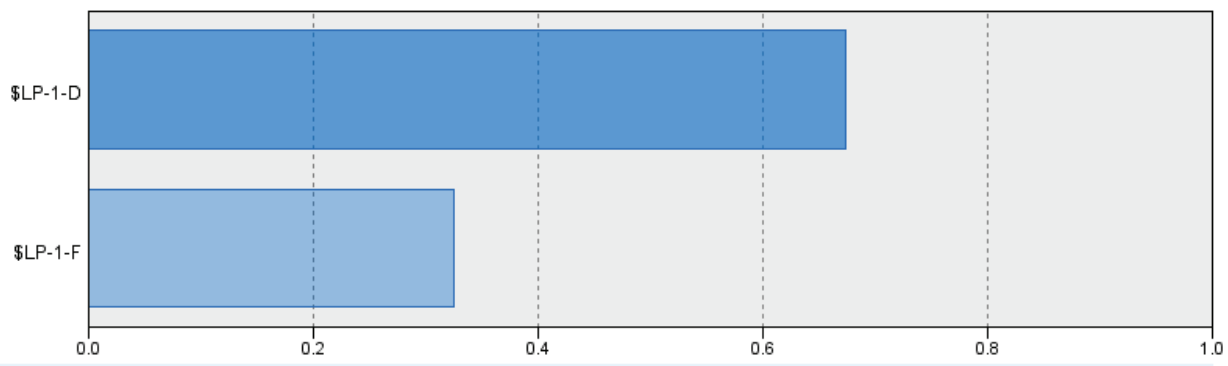

Not: \$LP-1-D: Davranış Modülü | \$LP-1-F: Finansal Modül

Modül geliştirme çalışmalarında olduğu gibi elde edilen nihai model entegrasyonunun hem model geliştirme hem de örneklem dişı verisi üzerinden Gini değerleri hesaplanmıştır. Model geliştirme örneklemi üzerinde \%56 Gini değerine sahip olan modelin örneklem dışı verisi üzerinde de \%68,5 Gini değerine sahip olduğu görülmüş olup model örneklem dışı verisi üzerinde daha iyi performans göstermiştir.

\subsubsection{Yapay Sinir Ağları Analizi}

Yapay sinir ağlarına ait teorik bilgiye "2.2.4. Yapay Sinir Ağları" bölümünde yer verilmiş olup bu bölümde yapılan çalışmanın detayları açıklanacaktır. 
Yapay sinir ağları (YSA) model çalışmasında, yöntemin değişkenler arasında çeşitli bağlar kurmak suretiyle hatayı minimize etmeye çalışması hususu göz önünde bulundurularak, lojistik regresyon çalışmasından farklı olarak modüler yapı kullanılmamış, davranış ve finansal modüllerin geliştirilmesinde kullanılan kısa değişken listeleri birleştirilerek tek bir değişken listesi üzerinden YSA modeli kurulmuştur.

YSA ve Lojistik modellerin kıyaslanması sürecinde veri seti üzerinde herhangi bir yanlılık oluşmaması adına herhangi farklılığa gidilmeyerek aynı örneklem üzerinden çalışmalar yürütülmüştür.

Ramchoun ve ark. (2016) çalışmalarında yapay sinir ağları ile tahmin sürecinde çok katmanlı algılama (Multilayer Perceptron / MLP) ve ileri beslemeli yapıların başarılı sonuçlar sağladığı belirtilmiştir ve literatürde de bu yöntem kredi skorlamasında tercih edilmektedir (Abdou, El-Masry ve Pointon, 2007). Firmaların temerrüte düşme olasılığının hesaplanmasını konu edinen bu çalısmada da çok katmanlı algılayıcı ve ileri beslemeli yapay sinir ağlarıyla tahmin yöntemi temel alınmıştır.

Önceki bölümlerde belirtildiği üzere yapay sinir ağlarında girdiler, ağırlıklar, toplama fonksiyonu, aktivasyon fonksiyonu ve çıtılar olmak üzere beş temel öge bulunmaktadır. Çok değişkenli bir YSA modelinde yer alan gizli katman sayısı, gizli katmanda yer alacak işlem eleman sayısı, gizli katmanda ve girdi katmanında yer alacak aktivasyon fonksiyonları ile öğrenme yöntemlerine gibi parametrelerin belirlenmesi büyük önem taşımaktadır.

Literatür araştırmaları sırasında, yukarıda bahsedilen ögelerin belirlenmesi aşaması için iyi uygulama önerisinin bulunmadığı, genellikle çalışmalarda deneme yanılma yöntemiyle optimum değerlere ulaşılmaya çalışıldığı görülmüştür.

Çalışmada SPSS Modeler programının yapay sinir ağları node'u kullanılmış olup, yukarıda bahsedilen ögelerden aktivasyon fonksiyonunun SPSS Modeler tarafından otomatik olarak belirlenmesine izin verilmiştir. Aktivasyon fonksiyonu olarak uygulamalarda genel olarak tercih edilen sigmoid fonksiyon kullanılmışıı (Al Doori 
ve Beyrouti, 2014). SPSS Modeler, YSA modellerinde öğrenme katsayısını ve momentum katsayısını otomatik olarak iterasyon yoluyla tespit etmektedir.

YSA çalışmalarında modelleme örneklemi mutlak suretle öğrenme ve test verisi olarak ikiye ayrılmaktadır. Söz konusu çalısmada da kitlenin \%80'i (17.139 gözlem) öğrenme, \%20'si (4.783 gözlem) test veri seti olarak ayrılmıştır.

Modele konu olacak girdi değişken sayısı, önceki bölümlerde belirtilen, çeşitli analizlerle belirlenmiş olup, YSA model geliştirme çalışmasında toplam 18 adet finansal ve 11 adet davranış girdi değişkeni kullanılmışır.

Model bir girdi katmanı, bir gizli katman ve bir çıkış katmanı olmak üzere üç katmandan oluşmaktadır. Literatürde yapılan araştırmalarda genel olarak gizli katman sayısına model geliştirici tarafından karar verildiği, çoğunlukla bir veya iki gizli katman içeren ağların daha iyi sonuçlar ürettiği ve tek gizli katmanlı YSA modellerinin daha çok tercih edildiği görülmüştür (Pacelli ve Azzolini, 2011). Gizli katman sayısının arttıııması; ağın öğrenim döngü sayısını ve dolayısıyla eğitim süresini, aynı zamanda da fazla öğrenme ile tahminleme yerine sonuç ezberleme olasıllğını arttırmaktadır. Bu nedenle düşük katman sayısı ile başlayarak yetersiz görülmesi durumunda katman sayısının arttırılmasına karar verilmiştir. Nitekim çalışmada genel uygulamalarda olduğu gibi bir gizli katman kullanılan YSA modeli, iki katmanlı YSA modelinden daha iyi sonuç üretmiş ve model tek gizli katman üzerinden geliştirilmiştir. Genel olarak literatürde yer alan çalışmalarda da performans sonuçları üzerinden gizli katman sayısına yer verilmektedir (Brown ve Mues, 2012). Ayrıca karmaşık modellerde genel olarak bir gizli katmanlı modeller tercih edilmektedir (Zhao ve ark., 2015).

Gizli katman sayısı kadar gizli katmanda yer alan nöron sayısı da YSA modellerinde oldukça önem taşımaktadır. Nöron sayısı SPSS Modeler tarafından otomatik olarak belirlenebilmekle birlikte deneme yanılma yöntemiyle de seçilebilmektedir. Literatürde yer alan çalışmalarda genel olarak gizli katmanda yer alacak nöron sayısı belirlenirken hata karelerinin toplamının minimize edilmesi hedeflenmektedir (Bekhet ve Kamel Eletter, 2014). Çalısmamızda da nöron sayısı seçimini 'hatada minimum nispi değişiklik' yöntemine göre yapılmıştır. Bu 
doğrultuda SPSS Modeler uygulaması tarafından optimum değer olarak 7 nöronun önerilmesi üzerine, geliştirme verisinin 17.139 gözlem barındırıyor olması da göz önünde bulundurularak, modelin 7 nöron ile geliştirilmesine karar verilmiştir. Nihai YSA model özeti aşağıda gösterilmiştir:

Şekil 5: YSA - Model Özeti

\begin{tabular}{|l|l|}
\hline Target & TOTAL_DEFAULT_d \\
\hline Model & Multilayer Perceptron \\
\hline Stopping Rule Used & $\begin{array}{l}\text { Minimum relative change in error } \\
\text { achieved }\end{array}$ \\
\hline Hidden Layer 1 Neurons & 7 \\
\hline
\end{tabular}

Not: Şekil yazar tarafından hazırlanmıştır.

Ayrıca tüm bunların yanında, nihai YSA modeline ait ağ yapısı da aşağıda verilen Şekil 6'da gösterilmiştir:

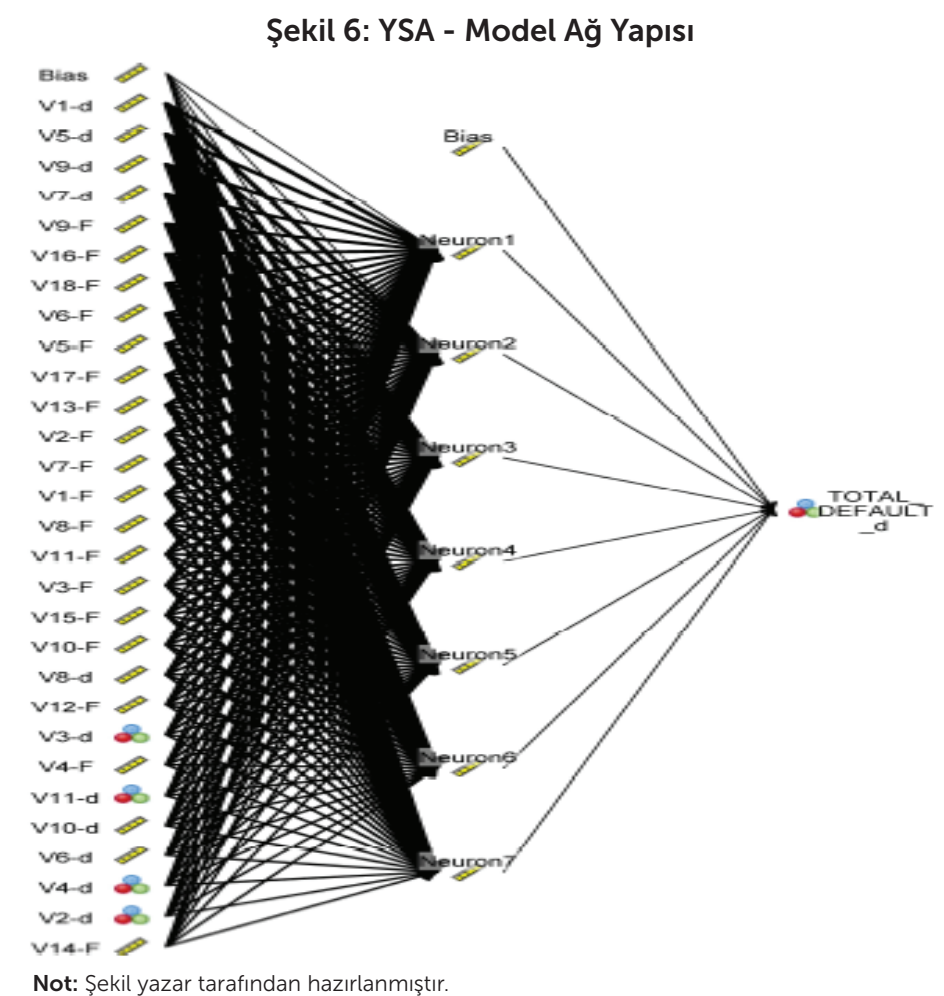


Ağ yapısında oluşan ve temerrüt olasılığını tahminleme aşamasındaki karar mekanizmasında yer alan değişkenlerin anlamlılığı incelendiğinde firmanın son 12 aydaki finansal sistemde yer alan toplam riskinin toplam limitine oranı değişkeni ile firmanın son 36 aydaki ödenmemiş çek ve senetlerine ait toplam tutar değişkeninin temerrüt olasıllı̆ını açıklamada diğer değişkenlere nazaran daha başarılı olduğu görülmüştür.

Elde edilen modelin performans sonuçlarını analiz etmek için modelin Gini değeri hesaplanmıştır. Model geliştirme örneklemi üzerinden modelin Gini değerinin \%76,2 olduğu görülmüş olup, örneklem dışı verisinde modelin ayırt etme gücü düşüş göstererek \%60,7 olmuştur.

\section{Sonuç}

Finansal sistemin istikrarlılığı, sistemin ana faaliyet konusu olarak adlandırabileceğimiz kredi verme işleminin kalitesi ile doğru orantılıdır. Geçmiş dönemde yaşanan global finansal krizleri genel olarak incelediğimizde, sağlıksız kredi karar süreçlerinin krizlerin temelinde yer aldığı görülmektedir. Bankacılık sektöründe kredi süreci; kredi pazarlaması, tahsisi, izlemesi ve kredinin geri ödenmemesi durumunda takip aşamasından oluşmaktadır. Özellikle kredi tahsis ve izleme aşamalarında müşterinin kapsamlı değerlendirilmesi ile muhtemel zararların önüne geçilebilmektedir.

Bankalar müşterilerinden kaynaklı oluşabilecek muhtemel zararları minimize etmek amacıyla geçmişte uzman görüşüne dayalı yöntemlerle, günümüzde ise çeşitli istatistiki yöntemler ile geliştirilmiş modelleri kullanarak, müşterilerinin temerrüt olasılığını tahmin etmeye çalışmaktadırlar. Kredi pazarlama, tahsis ve izleme aşamalarında oldukça etkin bir faktör olan temerrüt olasılığı, Türkiye Finansal Raporlama Standartları 9'un kullanıma alınması ile sadece müşteri yönetiminde bir faktör olmaktan çıkarak karşılık hesaplamalarında da kullanılmaya başlanmıştır. Böylelikle temerrüt olasılığı parametresi direkt olarak finansal tabloları etkilemeye başlamış ve bankaların söz konusu modellere daha çok odaklanmasına neden olmuştur. 
Geçmişten bu yana temerrüt olasılığı modellemelerinde diskriminant analizleri, lojistik regresyonlar, çoklu regresyon analizi, karar ağaçları en çok kullanılan istatiksel yöntemler olarak karşımıza çıkmaktadır. Son yıllarda işlenebilir verinin büyük kütlelere ulaşması nedeniyle verinin sağlıklı işlenebilirliği ve dinamik bir yapıya sahip olması nedeniyle temerrüt olasılığı modellerinde yapay sinir ağları gibi makine öğrenmesine dayalı sistemler, özellikle akademik çalışmalarda, kullanılmaya başlanmıştır. Bankacılık sektöründe ise kredi müşterilerin kredibilitesinin izlenmesi aşamasında faydalanılan erken uyarı sistemlerinde makine öğrenmesine dayalı sistemler kullanılabilmektedir.

Çalışmada geleneksel olarak kredi skorlaması alanında kullanılan lojistik regresyon modeli ile yapay sinir ağları modeli oluşturulmuş ve söz konusu modellerin hem geliştirme hem de örneklem dışı veri setleri üzerinden performans analizleri gerçekleştirilmiştir. Modelin temerrüde düşmüş (kötü) ve temerrüde düşmemiş (iyi) firmaları ne kadar iyi ayrıştırabildiğinin analizi için Gini değeri kullanılmıştır.

Gerçekleştirilen analizler sonucunda geliştirme veri setinde yapay sinir ağlarının lojistik regresyona kıyasla daha iyi sonuç gösterdiği, örneklem dışı veriler kullanıldığında ise iki modelde de performans anlamında ciddi düşüşler yaşandığı ve lojistik regresyonun yapay sinir ağlarına kıyasla daha başarılı performans sergilediği görülmüştür. Bu husus lojistik regresyonu yapay sinir ağlarına nazaran daha başarılı kılsa da son yıllarda yapılan araştırmalar yapay sinir ağları gibi makine öğrenmesine dayalı sistemlerin birçok farklı alanda başarılı sonuçlar ürettiğini göstermektedir.

Önümüzdeki çalışmalarda, veri setinin daha da birikmesi ile beraber kurumsal krediler üzerinden yapılacak olan analizlerde, yapay sinir ağlarının daha başarılı sonuçlar üreteceği düşünülmektedir. Ayrıca çalışmada özellikle yapay sinir ağları model mimarisi oluşturulurken birçok seçimin modelleme yazılımına bırakılarak otomatize edildiği de göz önünde bulundurulduğunda, mimari yapının seçiminde istatistiksel yöntemlerden faydalanılmasının, bilgi kriteri ve $F$ testi ile nöron sayısının belirlenmesinin yapay sinir ağları modelinin başarısına katkı sağlayacağı düşünülmektedir. 


\section{Son Notlar}

${ }^{1}$ Rasyo içeren değişkenlerde paydanın 0 değerini alması sebebiyle değişken tanımsız sonuç vermekte ve hesaplanamamaktadır.

Finansal Destek: Yazar bu çalışma için finansal destek almamıştır.

\section{Kaynakça}

Abdou, H. A., \& Pointon, J. (2011). Credit Scoring, Statistical Tecniques and Evaluatiın Criteria: A Review of the Literature. Intelligent Systems in Accounting, Finance \& Management, 18(2-3), 5988.

Abdou, H., El-Masry, A., \& Pointon, J. (2007). On the Applicability of Credit Scoring Models in Egyptian Banks. Banks and Bank Systems, 2(1), 4-20.

Abdou, H., Pointon, J., \& El-Masry, A. (2008). Neural Nets versus Conventional Techniques in Credit Scoring in Egyptian Banking. Expert Systems with Applications, 35, 1275-1292.

Al Doori, M., \& Beyrouti, B. (2014). Credit Scoring Model Based on Back Propagation Neural Network Using Various Activation and Error Function. International Journal of Computer Science and Network Security, 14(3), 16-24.

Alavala, C. (2007). Fuzzy Logic and Neural Networks. India: New Age International Publishers.

Ataseven, B. (2013). Yapay sinir ağları ile öngörü modellemesi. Öneri Dergisi, 10(39), 101-115.

Ballı, M. T. (2014). Yapay sinir ağları ile talep tahmini ve gıda sektöründe uygulanması. (Yüksek lisans tezi). Yıldız Teknik Üniversitesi Sosyal Bilimler Enstitüsü, İstanbul.

Bayır, F. (2006). Yapay sinir ağları ve tahmin modellemesi üzerine bir uygulama. İstanbul: (Yüksek lisans tezi). İstanbul Üniversitesi Sosyal Bilimler Enstitüsü, İstanbul. Erişim Adresi: http://acikerisim. istanbul.edu.tr/bitstream/handle/123456789/26274/41491.pdf? sequence=1\&isAllowed=y

Bekhet, H., \& Kamel Eletter, S. (2014). Credit risk assessment model for Jordanian commercial banks: Neuralscoring approach. Review of Development Finance, 4, 20-28.

Bishop, C. (1995). Neural Networks for Pattern Recognition. Oxford: Clarendon Press.

Brown, I., \& Mues, C. (2012). An experimental comparison of classification algorithms for imbalanced credit scoring data sets. Expert Systems with Applications, 39, 3446-3453.

Budak, H., \& Erpolat, S. (2012). Kredi Riski Tahmininde Yapay Sinir Ağları ve Lojistik Regresyon Analizi Karşılaşıııılması. Online Academic Journal of Information Technology, 3, 23-30.

Chih-Fong, T., \& Jhen-Wei, W. (tarih yok). Using Neural Network Ensembles for Bankruptcy Prediction and Credit Scoring.

Çevik, K., \& Dandıl, E. (2012). Bilişim Teknolojileri Dergisi, 5(1), 19-28.

Demirbulut, Y., Aktaş, M., Kalıpsız, O., \& Bayracı, S. (2017). İstatistiksel ve Makine Öğrenimi Yöntemleriyle Kredi Skorlama. CEUR-WS (s. 273-284). Antalya: Turkish National Software Engineering Symposium. 
Desai, V., Crook, J., \& Jr. Overstreet, G. (1996). A Comparison of Neural Networks and Linear Scoring Models in the Credit Union Environment. European Journal of Operational Research, 95, 24-37.

Dinçer, H., Hacıoğlu, Ü., \& Yüksel, S. (2016). Performance Assessment of Deposit Banks with CAMELS Analysis using Fuzzy ANP-MOORA Approaches and an Application on Turkish Banking Sector. Asian Research Consortium, 6(2), 32-56.

Donel, B. (2012). Yapay Sinir Ağları Yöntemiyle Kredi Skorlama. (Yüksek Lisans Tezi). İstanbul Teknik Üniversitesi Sosyal Bilimler Enstitüsü, İstanbul.

Ersoy, E., \& Karal, Ö. (2012). Yapay Sinir Ağları ve İnsan Beyni. Insan ve Toplum Bilimleri Araştırmaları Dergisi, 1(2), 188-205.

Han, L., Han, L., \& Zhao, H. (2013). Orthogonal support vector machine for credit scoring. Engineering Applications of Artificial Intelligence, 26(2), 669-936.

Hooman, A., Marthandan, G., Wan Yusoff, W., Omid, M., \& Karamizadeh, S. (2016). Statistical and data mining methods in credit scoring. The Journal of Developing Areas, 50(5), 371-381.

Irwin, R. (1965). Credit Management Handbook, National Associotion of Credit Management. Oxford: Credit Research Foundation.

Jensen, H. (1992). Using Neural Networks for Credit Scoring. Managerial Finance, 18(6), 15-26.

Kamuyu Aydınlatma Platformu. (2019). KAP Yatımcı Kuruluşlar. 09/28/2019. Erişim Adresi: https:// www.kap.org.tr/tr/sirketler/YK

Kangal, D. P. (2017). Kredi skorlaması ve kullanılan yöntemlerin karşılaştırılmasına yönelik bir uygulama. (Yüksek lisans tezi). Bahçeşehir Üniversitesi Sosyal Bilimler Enstitüsü, İstanbul.

Karimi, A. (2014). Credit Risk Modeling for Commercial Banks. International Journal of Academic Research in Accounting, Finance and Management Sciences, 4(3), 187-192.

Keskenler, E. F., \& Keskenler, M. F. (2017). Geçmişten Günümüze Yapay Sinir Ağları ve Tarihçesi. Takvim-i Vekayi, 5(2), 8-18.

Keskinkılıç, T. (2008). Temerrüt Olasılığının Tespitine Illişkin Ampirik Bir Çalışma. (Yüksek lisans tezi). Gazi Üniversitesi Sosyal Bilimler Enstitüsü, Ankara.

Kılıç, S. (2015). Binary logistic regression analysis. Journal of Mood Disorders, 5(4), 191-194. doi:10.5455/jmood.20151202122141

Koç, S. (2018). Lojistik Regresyon Yöntemi ile Kredi Skorlama Uygulaması. (Yüksek Lisans Tezi). Kadir Has Üniversitesi Sosyal Bilimler Enstitüsü, İstanbul.

Kurtaran Çelik, M. (2010). Bankaların Finansal Başarısızlıklarının Geleneksel ve Yeni Yöntemlerle Öngörüsü. Yönetim ve Ekonomi, 17(2), 129-143.

Lee, M. K., Cheung, C. M., \& Chen, Z. (2005). Acceptance of Internet-based Learning medium: the Role of Extrinsic and Intrinsic Motivation. Information \& Management, 42, 1095-1104.

Lee, T.-S., Chiu, C.-C., Lu, C.-J., \& Chen, I.-F. (2002). Credit scoring using the hybrid neural discriminant technique. Expert Systems with Applications, 23, 245-254.

Malhotra, R., \& Malhotra, D. (2002). Differentiating Between Good Credits and Bad Credits Using Neuro-fuzzy Systems. European Journal of Operational Research, 136, 190-211. 
Marques, A., García, V., \& Sánchez, J. (2012). Exploring The Behaviour of Base Classifiers in Credit Scoring Ensembles. Expert Systems with Applications, 39, 10244-10250.

Marques, G., \& Marques, S. (2013). A literature review on the application of evolutionary computing to credit scoring. Journal of the Operational Reserch Society, 64, 1384-1399.

Merkez Bankası. (2019, 09 01). Elektronik Veri Dağıtım Servisi. 09/09/2019. Erişim Adresi: https:// evds2.tcmb.gov.tr: https://evds2.tcmb.gov.tr/index.php?/evds/serieMarket/\#collapse_4

Niklis, D., Doumpos, M., \& Zopounidis, C. (2012). Combining Market and Accounting-based Models for Credit Scoring Using a Classification Scheme Based on Support Vector Machines. Financial Engineering Laboratory, 1-28.

Öker, A. (2007). Ticari bankalarda kredi ve kredi riski yönetimi-bir uygulama. (Doktora tezi). Marmara Üniversitesi Sosyal Bilimler Enstitüsü, İstanbul. Erişim Adresi: http://www.tk.org.tr/APA/apa_2.pdf Öztemel, E. (2012). Yapay Sinir Ağları. İstanbul: Papatya Yayıncılı.

Pacelli, V., \& Azzollini, M. (2011). An Artificial Neural Network Approach for Credit Risk Management. Journal of Intelligent Learning Systems and Applications, 3, 103-112. doi:10.4236/ jilsa.2011.32012

Ramchoun, H., Janati Idrissi, M., Ghanou, Y., \& Ettaouil, M. (2016). Multilayer Perceptron: Architecture Optimization and Training. International Journal of Interactive Multimedia and Artificial Intelligence, 4(1), 26-30. doi:10.9781/ijimai.2016.415

Řezáč „, M., \& Řezáč, F. (2011). How to Measure the Quality of Credit Scoring Models. Finance a úvěr: Czech Journal of Economics and Finance, 61(5), 486-507.

Soni, A., \& Abdullahi, A. U. (2015). Using Neural Networks for Credit Scoring. International Journal of Science, Tecnology\&Management, 04(05), 26-31.

Soydemir, S. (2019). Bankacılık Sermaye Yeterliliği ve Yeni Ekonomi Programı. Ufuk Üniversitesi Sosyal Bilimler Enstitüsü Dergisi, 8(15), 301-325.

Taylan, D., \& Aydın, T. (2018). The Trend Analysis of Lakes Region Precipitation Data in Turkey. Cumhuriyet Sciences Journal, 39(1), 258-273.

Tsai, C.-F., \& Wu, J.-W. (2008). Using Neural Network Ensembles for Bankruptcy Prediction and Credit Scoring. Expert Systems with Applications, 34, 2639-2649.

Türkiye Bankalar Birliği. (09.09.2019). Türkiye Bankalar Birliği Risk Merkezi Aylk Bülten Haziran 2019. Erişim Adresi: https://www.riskmerkezi.org/Content/Upload/istatistikiraporlar/ekler/1926/Risk Merkezi_Aylik_Bulten_Ozeti_Haziran_2019.pdf

Türkiye Bankalar Birliği Çalışma Grubu. (2006). Kredi Riski Modelleri. Bankacılar Dergisi, 57, 33-66. 09.09.2019. Erişim Adresi: https://www.tbb.org.tr/Dosyalar/Arastirma_ve_Raporlar/kredi_riski_ modelleri.pdf

Uruş, A. (2019). Finansal Krizler Sonrası Uygulanan Regülasyonlar ve Etkinliği. Manisa Celal Bayar Üniversitesi I.I.B.F., 26(1), 32-48.

West, D. (2000). Neural network credit scoring models. Computers \& Operations Reserch, 27, 11311152. 
Yakut, E., \& Elmas, B. (2013). işletmenin Finansal Başarısızlığının Veri Madenciliği ve Diskriminant Analizi Modelleri ile Tahmin Edilmesi. Afyon Kocatepe Üniversitesi, IiBF Dergisi, 15(1), 261-280.

Zekic-Susac, M., Sarlija, N., \& Bensic, M. (2005). Small Business Credit Scoring: A Comparison of Logistic Regression, Neural Network, and Decision Tree Models. Intelligent Systems in Accounting, Finance \& Management: International Journal, 13(3), 133-150.

Zhao, Z., Xu, S., Kang, B., Kabir, M., Liu, Y., \& Wasinger, R. (2015). Investigation and improvement of multi-layer perception neural networks for credit scoring. Expert Systems with Applications, 42, 3508-3516.

Zhu, Y., Xie, C., Sun, B., Wang, G.-J., \& Yan, X.-G. (2016). Predicting China's SME Credit Risk in Supply Chain Financing by Logistic Regression, Artificial Neural Network and Hybrid Models. Sustainability, 8(433), 1-17. 
